MARIA DA GRAÇA BONANÇA BARBOSA

OS PRINCÍPIOS DO PROCESSO COLETIVO E O PAPEL DO JUIZ EM PROL DA EFETIVIDADE DA REPARAÇÃO DO DANO MORAL COLETIVO NA JUSTIÇA DO TRABALHO

\author{
DOUTORADO EM DIREITO
}

Orientador: Professor Titular Sergio Pinto Martins

FACULDADE DE DIREITO DA UNIVERSIDADE DE SÃO PAULO

SÃO PAULO

2014 


\section{OS PRINCÍPIOS DO PROCESSO COLETIVO E O PAPEL DO JUIZ EM PROL DA EFETIVIDADE DA REPARAÇÃO DO DANO MORAL COLETIVO NA JUSTIÇA DO TRABALHO}

Tese apresentada à Banca Examinadora, no âmbito do Programa de Pós-Graduação da Faculdade de Direito da Universidade de São Paulo, como exigência parcial para a obtenção do título de Doutora em Direito, sob orientação do Professor Titular Sergio Pinto Martins.

FACULDADE DE DIREITO DA UNIVERSIDADE DE SÃO PAULO

SÃO PAULO 
FOLHA DE APROVAÇÃO

Maria da Graça Bonança Barbosa

OS PRINCÍPIOS DO PROCESSO COLETIVO E O PAPEL DO JUIZ EM PROL DA EFETIVIDADE DA REPARAÇÃO DO DANO MORAL COLETIVO NA JUSTIÇA DO TRABALHO 


\section{AGRADECIMENTOS}

Nada se constrói sozinho. Ilude-se aquele que pensa o contrário. Muito tenho a agradecer neste momento. Primeiramente a Deus e aos seus anjos, físicos e espirituais, que me sustentaram durante o árduo trabalho de pesquisa e elaboração de uma tese de doutorado. A todos os professores da Faculdade de Direito da Universidade de São Paulo que contribuíram, ainda que não saibam, para a realização deste trabalho e, em especial, ao meu orientador, Professor Sergio Pinto Martins pela irrestrita confiança depositada e pela liberdade assegurada na pesquisa e elaboração do texto. Também não poderia deixar de agradecer a todos os funcionários dessa Faculdade por se mostrarem amáveis e solícitos quando precisei, e, como não posso nominá-los todos, o faço na pessoa de Marli de Moraes pelo auxílio na pesquisa e na formatação do trabalho. Ao Tribunal Regional do Trabalho da $15^{\mathrm{a}}$. Região pelo apoio incondicional sem o qual nada teria sido feito. Agradeço aos colegas Rodrigo Adélio Abrahão Linares e Priscila de Freitas Cassiano Nunes, competentes juízes do Trabalho que participam ativamente da jurisdição, tal como defendo no presente trabalho, por me terem me substituído no período da licença para estudos, o que fez com que minha ausência não acarretasse o menor prejuízo para a prestação jurisdicional. A todos os valorosos servidores da $5^{\text {a }}$ Vara do Trabalho de São José dos Campos por sua parceria e por me inspirar a querer fazer sempre o melhor, os quais são homenageados na pessoa da minha secretária de audiências Vera Lucia Tamegão Lopes Barros, cuja bondade e presteza tornam meu dia a dia mais leve, por se ter se prontificado a dedicar seu tempo e emprestar seus conhecimentos para a revisão gramatical e ortográfica deste trabalho. Ao amigo de última hora, Antonio Gidi, que me ajudou a decifrar alguns dos enigmas das class actions. Falei de anjos no início destes agradecimentos e concluo falando deles: agradeço ao meu marido, Sergio, por estar sempre ao meu lado e por eu saber que posso, de verdade, contar com seu apoio e incentivo. E a Carolina, filha querida, que dará os primeiros passos no aprendizado do Direito neste ano que se inicia, desejo que eles te levem até a felicidade, como fizeram comigo. 


\section{Dedicatória}

Dedico esta tese de doutorado à minha mãe, Helena Dolgovas Bonança, por me ter me dado a vida, os bons ensinamentos e exemplos e, em especial, por torcer, vibrar, rezar, acreditar e estar comigo, em todos os momentos da minha vida. 


\section{RESUMO}

A presente tese apresenta uma base principiológica em prol da efetividade da reparação do dano moral coletivo e destaca a participação ativa do juiz do Trabalho visando alcançar uma indenização que estabeleça uma conexão entre o dano e a reparação em benefício da comunidade lesada. Com base na Constituição e nos projetos de codificação do processo coletivo, em especial do Projeto de Lei $\mathrm{n}^{\circ}$ 5.139/2009, foram apontados os princípios do acesso à Justiça e devido processo legal como "princípios balizas", pois deles decorrem ou defluem os princípios do processo coletivo e constituem os fundamentos para uma atuação judicial que priorize a efetividade da reparação do dano moral coletivo. A participação ativa do juiz do Trabalho e sua atuação discricionária e criativa no arbitramento da indenização por dano moral coletivo foram fundamentadas nos princípios da relevância social da tutela e da proporcionalidade e razoabilidade, sem prescindir de critérios próprios que devem nortear essa decisão, destacando-se que o dano moral coletivo não corresponde à somatória dos danos morais individuais e com eles não se confunde. Destacou-se o novo critério da punição do enriquecimento sem causa do ofensor que reforça a possibilidade de condenação por dumping social na Justiça do Trabalho, defendendo-se, entretanto, que esse critério seja considerado como agravante para a condenação e não como fundamento para uma condenação suplementar a tal título. A presente tese defende que a indenização do dano moral coletivo deve representar o tríplice efeito, por meio da punição ao ofensor, o fim pedagógico para a sociedade e a compensação para a comunidade lesada, e que apenas o primeiro desses efeitos é alcançado quando a indenização é remetida para o Fundo de Amparo ao Trabalhador FAT. Demonstra-se que o FAT não tem como objetivo reparar o dano moral coletivo reconhecido pelas decisões da Justiça do Trabalho e, ante a omissão da legislação brasileira, invoca-se o direito comparado, consistente na solução do tipo cy press ou fluid recovery das class actions do direito norte-americano, que considera a fórmula do "mais próximo do possível" entre o dano e a reparação. Apontam-se os fundamentos que podem nortear essa decisão, extraídos do próprio ordenamento jurídico pátrio e aborda-se a questão dos limites do pedido deduzido nas ações coletivas que indicam o FAT como destinatário da indenização. Defende-se, ainda, que o juiz do Trabalho considere, na sua decisão, o "sentir coletivo" representado pelos sentimentos da comunidade afetada pelo dano e adote medidas que possam viabilizar a percepção dessa coletividade quanto à reparação, e considere os efeitos compensatório e pedagógico da indenização, apresentando-se uma proposta de gradação como referência, com tal objetivo. O papel do juiz do Trabalho é indicado como fundamental para uma mudança de perspectiva para a efetividade da reparação, apontando-se alguns dos problemas que impedem o juiz de dedicar-se à condução e solução das complexas lides coletivas e também algumas propostas para alteração de um sistema jurídico que ainda privilegia as ações individuais. Em conclusão, a presente tese pretende impulsionar uma reflexão sobre os efeitos que devem ser alcançados pelas condenações por danos morais coletivos na Justiça do Trabalho em prol da efetividade da respectiva reparação.

Palavras Chaves: Efetividade. Dano Moral Coletivo. Reparação cy pres ou fluid recovery. Fundo de Amparo ao Trabalhador - FAT. Princípios do Processo Coletivo. Papel do juiz do Trabalho 


\begin{abstract}
This thesis presents a principled basis in favor of the effectiveness of collective moral damage compensation and highlights the importance of an active participation of the labor judge aimed at attaining compensation to establish a connection between damage and compensation in favor of the aggrieved community. Based on the Constitution and on collective process codified projects, in particular the Bill $\mathrm{n}^{\circ} 5.139 / 2009$, we pointed the principles of access to justice and the due process of law as the "fundamental principles" because it is from them that the principles of collective process proceed and they constitute the basis for a court action that prioritizes the effectiveness of collective moral damages compensation. The active participation of the Labor judge and his/her discretionary and creative performance in the arbitration of collective compensation for moral damages were based on the principles of social relevance of authority, reasonableness and proportionality, without the exclusion of his/her own criteria that should guide his/her decision, it is worth mentioning that collective moral damages do not correspond to the sum of individual moral damages and it should not to be confused with it. We emphasized the new punishment criterion of unjust enrichment of the offender which enhances the possibility of conviction for social dumping on Labor Courts, but at the same time asserting that this criterion should be considered as aggravating circumstances and not as a basis for an additional conviction. This thesis argues that collective compensation for moral damages should represent the threefold effect; punishing the offender, educating society and compensating the aggrieved community and that only the first of these effects is achieved when the compensation is sent to the FAT (Worker Support Fund). It is here demonstrated that the FAT (Worker Support Fund) is not meant to repair collective moral damages recognized by the decisions of the Labor Courts and, and due to the omission of Brazilian Law in this respect, we invoked the compared right, which is consistent with the cy press or fluid recovery solution for class actions in U.S. Law, which considers the "as close as possible" formula between damage and compensation. We indicate the basis to guide this decision, taken from the national legal system itself and we address the question of limits of claims filed in collective actions that indicate the FAT (Workers Assistance Fund) as a recipient of compensation. It is also argued that the Labor judge should consider, as he/she takes his/her decision, the " collective feeling" which represents the feelings of the community affected by the damage and that this judge should take steps to make it possible to realize this collective group as far as the compensation is concerned, and he/she should also consider the compensatory and teaching effects of the compensation, we presented a grading proposal to be used as a reference with this objective in mind. The role of the Labor judge is indicated as critical for changing the perspective of compensation effectiveness, we also point out some of the problems that prevent the judge from finding the solution for complex collective labors actions besides presenting some proposals for amendments of the legal system which still favors individual actions. In conclusion, this thesis aims to encourage a reflection about the effects of convictions for collective damages in Labor Courts and it favors compensation effectiveness.
\end{abstract}

Keywords: Effectiveness; Collective Moral Damage; Cy pres or fluid recovery compensation; FAT (Worker Assistance Fund); Collective Process Principles; Labor Judge Role 


\section{RIASSUNTO}

La presente tesi presenta una base di principi a favore dell'effettività del risarcimento del danno morale collettivo ed evidenzia la participazione attiva del magistrato del lavoro con l'obbiettivo di raggiungere un indennizzo che stabilisca una connessione tra il danno e il risarcimento in beneficio della comunità lesa. In base alla Costituzione e ai progetti di codificazione del processo collettivo, in particolare il Progetto di Legge $n^{\circ} 5.139 / 2009$, sono stati indicati i principi di accesso alla Giustizia e il dovuto processo legale come "principi cardini" poiché da loro derivano o provengono i principi del processo collettivo e costituiscono i fondamenti per un'azione giudiziaria che dia la priorità all'effettività del risarcimento del danno morale collettivo. La partecipazione attiva del giudice del Lavoro e la sua azione discrezionale e criativa nell'arbitrato dell'indennizzo per danno morale collettivo sono basati sui principi della rilevanza sociale della tutela e della proporzionalità e ragionevolezza, senza prescindere da criteri propri che devono guidare questa decisione, evidenziandosi che il danno morale collettivo non corrisponde alla sommatoria dei danni morali individuali e con loro non si confonde. Si è evidenziato il nuovo criterio della punizione dell'arricchimento senza causa dell'offensore che rafforza la possibilità di condanna per dumping social presso la Giustizia del Lavoro, difendendosi, frattanto, che questo criterio sia considerato come aggravante per la condanna e non come fondamento per una condanna supplementare a tal titolo. La presente tesi difende che l'indennizzo del danno morale collettivo deve rappresentare il triplice effetto, mediante la punizione dell'offensore, il fine pedagogico per la società e la compensazione alla comunità lesa, e che il primo di questi effetti è raggiunto soltanto quando l'indennizzo é inviato al Fondo di aiuto del Lavoratore - FAT (Fundo de Amparo ao Trabalhador). Si dimostra che il FAT non ha come obbiettivo risarcire il danno morale collettivo riconosciuto dalle decisioni della Giustizia del Lavoro e, di fronte all'omissione della legislazione brasiliana, si invoca il diritto comparato, consistente nella soluzione tipo $c y$ press o fluid recovery delle class actions del diritto nordamericano, che considera la formula "più realistica possibile" tra il danno e il risarcimento. Si indicano i fondamenti che possono guidare questa decisione, estratti dal proprio ordinamento giuridico pátrio e si tratta la questione dei limiti della richiesta dedotta dalle azioni collettive che indicano il FAT come destinatario dell'indennizzo. Si difende, anche, che il magistrato del Lavoro consideri, nella sua decisione, il "sentire collettivo" rappresentato dai sentimenti della comunità lesa dal danno e adotti misure che possano facilitare la percezione di questa collettività per quanto riguarda il risarcimento, e consideri gli effetti compensativo e pedagogico dell'indennizzo, presentando una proposta di gradazione come riferimento, con tale obbiettivo. Il ruolo del giudice del Lavoro è indicato come fondamentale per um cambiamento di prospettiva per l'effettività del risarcimento, indicandosi alcuni dei problemi che impediscono il giudice di dedicarsi alla conduzione e soluzione delle liti collettive ed anche alcune proposte per alterare un sistema giuridico che privilegia ancora le azioni individuali. In conclusione, la presente tesi pretende dare um impulso alla riflessione sugli effetti che devono essere raggiunti dalle condanne per danni morali collettivi presso la Giustizia del Lavoro a favore dell' effettività del corrispondente risarcimento.

Parole-chiave: Effettività. Danno Morale Collettivo. Risarcimento cy pres o fluid recovery. Fondo di Aiuto del Lavoratore - FAT. Principi del Processo Collettivo. Ruolo del Giudice del Lavoro 


\section{SUMÁRIO}

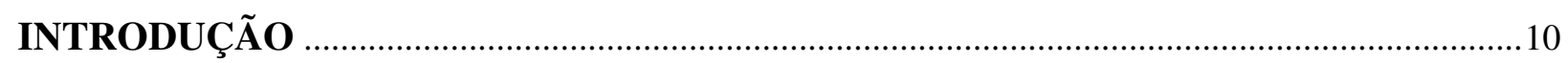

CAPÍTULO I. PRINCÍPIOS DO PROCESSO COLETIVO................................................... 15

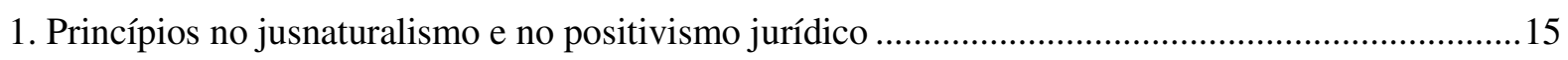

2. A constitucionalização dos princípios - o pós-positivismo ……….................................................17

3. Os principios gerais do processo e as Constituições brasileiras........................................................23

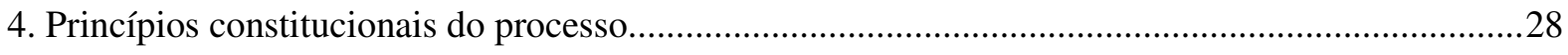

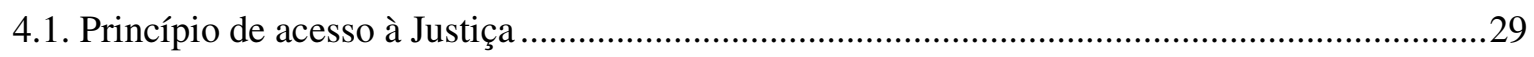

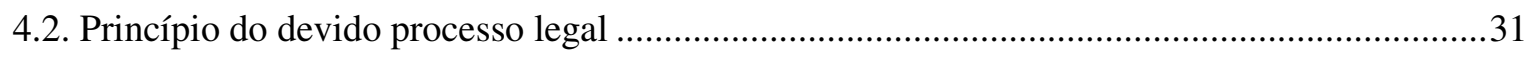

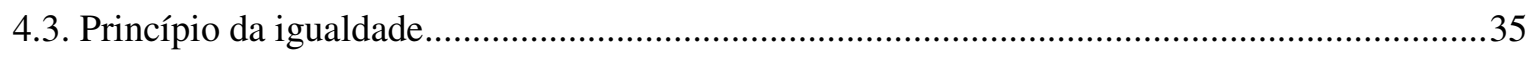

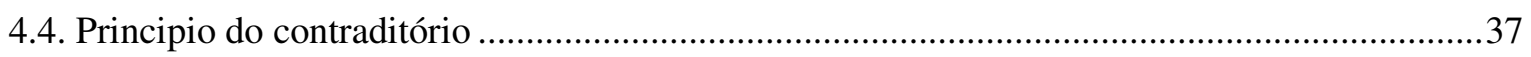

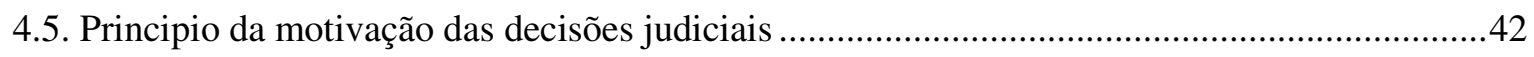

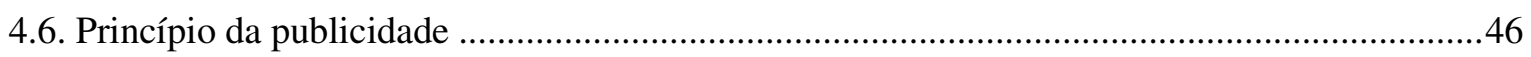

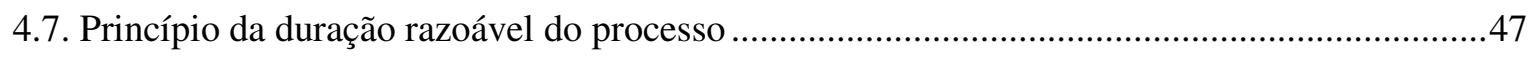

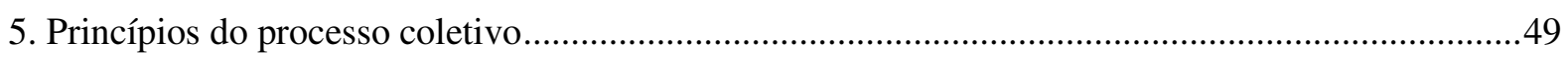

5.1. Princípios balizas: acesso à Justiça e devido processo legal......................................................58

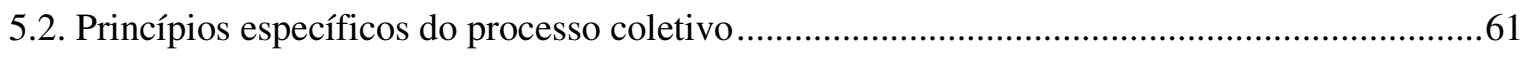

5.2.1. Princípio do amplo acesso à Justiça ............................................................................62

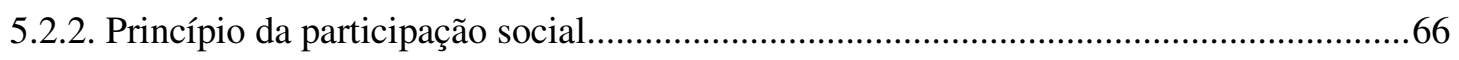

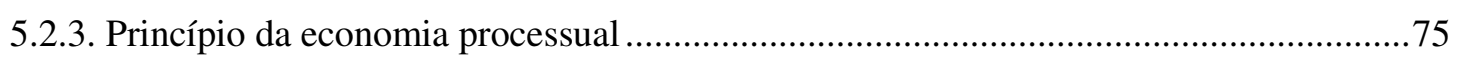

5.2.4. Princípios da adequação e da flexibilidade procedimental............................................8

5.2.5. Princípio da máxima efetividade da tutela coletiva.......................................................93

5.2.5.1. Princípio do interesse jurisdicional no conhecimento de mérito da ação

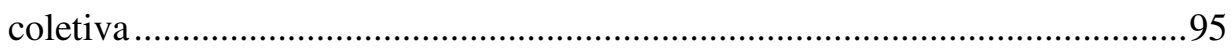

5.2.5.2. Princípio da integral precaução, prevenção e reparação do dano coletivo.......102

5.2.6. Princípio da motivação adequada ou específica da decisão judicial .............................103

5.2.7. Princípio da publicidade e ampla divulgação dos atos processuais ...............................110

5.2.8. Princípio da prioridade de tramitação do processo coletivo em todas as fases e

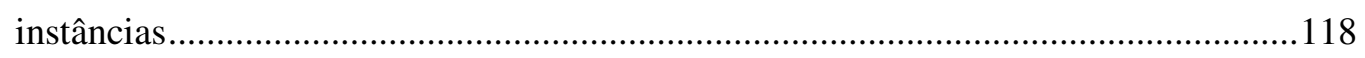

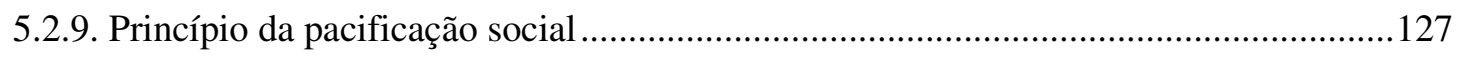

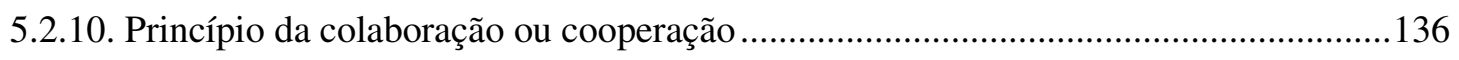

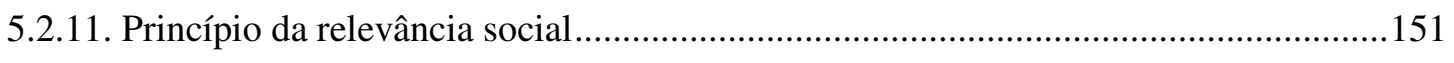

5.2.12. Princípio da proporcionalidade e razoabilidade .......................................................157

CAPITULO II. A REPARAÇÃO DO DANO MORAL COLETIVO

1. Dano moral individual e coletivo: base legal, diferenciação e evolução na doutrina e na jurisprudência

2. Os princípios do processo coletivo e a percepção do "sentir coletivo" pelo juiz do Trabalho 
3. Indenização por dano moral coletivo: critérios para arbitramento, natureza da reparação, destinação e limites do pedido

3.1. Critérios para arbitramento da indenização

3.2. Natureza da reparação do dano moral - do individual ao coletivo ...........................................208

3.3. A natureza compensatória da indenização do dano moral coletivo ...........................................217

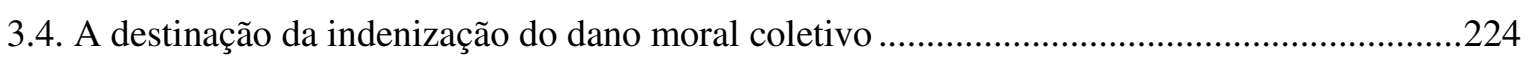

3.4.1. A inspiração no modelo norte-americano da class action: o fundo de direitos difusos.

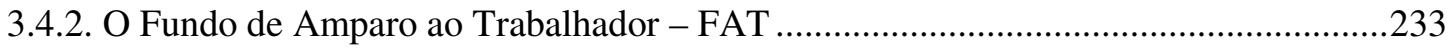

3.4.3. As propostas para uma nova regulação dos fundos de direitos difusos .........................241

3.5. A falta de conexão entre a reparação e o dano moral coletivo ...............................................252

3.5.1. Reparação cy pres ou fluid recovery - a solução das class actions nos EUA...............255

3.5.2. A adoção da fluid recovery ou cy pres pelo ordenamento brasileiro .............................261

3.5.3. Parâmetros para uma destinação que alcance os efeitos compensatório e pedagógico

3.5.4. A jurisprudência trabalhista e a destinação da indenização pelo dano moral coletivo.......

3.6. Obstáculos para a reversão da indenização pecuniária à coletividade lesada.........................28

3.6.1. Fundamentos para a reversão da indenização à coletividade ........................................220

3.6.2. O pedido e os limites à efetividade da reparação do dano moral coletivo .....................297

3.6.3. Pedido e causa de pedir - propostas legislativas e as lições do direito comparado em tema de preclusão e estabilização do processo.

\section{CAPITULO III. O PAPEL DO JUIZ NA REPARAÇÃo DO DANO MORAL COLETIVO}

1. O juiz: da arbitrariedade à neutralidade absoluta

2. O Judiciário nas Constituições que se seguiram às duas grandes revoluções do século XVIII.

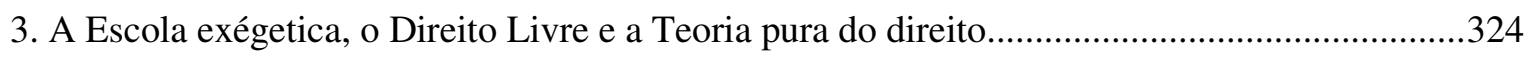

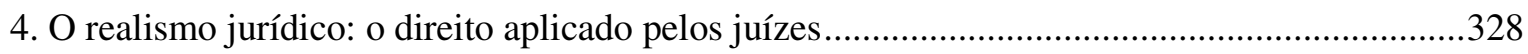

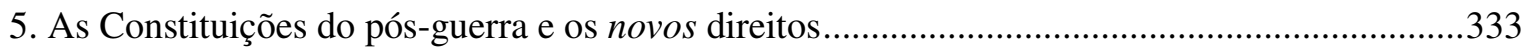

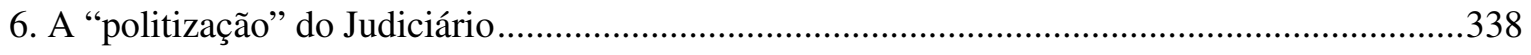

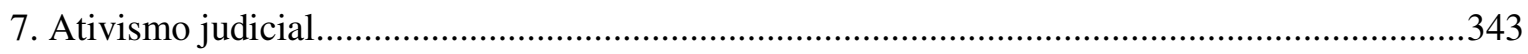

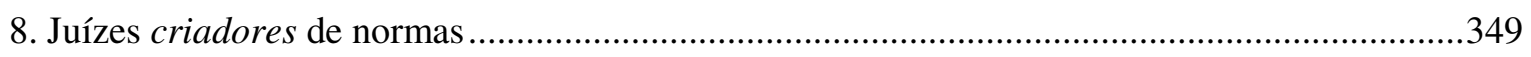

9. O juiz, a gestão judicial e a efetividade da reparação do dano moral coletivo .............................356 


\section{INTRODUÇÃO}

O tema da presente tese foi escolhido em razão de uma constatação feita na prática da atuação jurisdicional: não obstante tenha se tornado frequente o enfrentamento de pedidos de reparação do dano moral coletivo pelos juízes do Trabalho, os estudos empreendidos pela doutrina trabalhista eram, em sua grande maioria, sobre a indenização do dano moral individual.

Assim, o estudo poderia representar uma contribuição para o aperfeiçoamento da doutrina relativa à reparação dos danos morais coletivos e servir de subsídio para a jurisprudência trabalhista quanto a tal matéria.

Ainda no plano da delimitação do tema, verificou-se que o pedido deduzido nas respectivas ações coletivas indicava o Fundo de Amparo ao Trabalhador - FAT como destinatário das indenizações por dano moral coletivo, com fundamento no disposto no artigo 13 da Lei ${ }^{\circ} 7.347 / 85$ - LACP, e que essa era a solução apontada pela jurisprudência trabalhista de forma majoritária.

Embora o Fundo de Amparo ao Trabalhador - FAT tivesse objetivos bem definidos e conhecidos por todos, no que se refere ao pagamento do seguro-desemprego e abono anual aos trabalhadores, nunca se soube ao certo de que forma eram utilizados os recursos oriundos de condenações da Justiça do Trabalho, tampouco os juízes se detinham sobre a destinação final desses recursos.

Por fim, havia uma questão que estava a merecer melhor elucidação e que consistia na própria finalidade dessa condenação, pois se quanto ao dano moral individual era palpável a percepção do lesado quando recebia uma indenização a tal título, o mesmo não ocorria com a coletividade lesada pelo dano moral coletivo, já que o valor da indenização era remetido para o Fundo de Amparo ao Trabalhador - FAT.

Delimitava-se, assim, a proposta da presente tese, no sentido de se confirmar a possibilidade de o juiz do Trabalho destinar a indenização por dano moral coletivo em benefício da coletividade que suportou o prejuízo e, ainda, de ter essa coletividade a percepção de que houve, de fato, uma reparação e, finalmente, apresentar os fundamentos para que assim pudesse o juiz decidir. 
Para tanto, propôs-se enfrentar a questão da disciplina adotada pelo ordenamento jurídico brasileiro de remessa de valores oriundos das condenações por danos coletivos para um fundo estatal; bem como o pedido e sua limitação nas respectivas ações coletivas, além dos fundamentos que poderiam ser adotados pelos juízes do Trabalho em prol de uma efetiva reparação de danos morais coletivos.

Diante de um quadro de delimitação legal quanto à forma de destinação dos valores oriundos de condenações em ações coletivas, das lições da doutrina que apontavam o Fundo de Amparo ao Trabalhador - FAT como destinatário das indenizações por dano moral coletivo e de uma jurisprudência trabalhista majoritária no mesmo sentido, decidiuse iniciar o estudo pelos princípios do processo coletivo.

O estudo dos princípios do processo coletivo demonstrou ser de significativa importância, pois os princípios e institutos próprios do processo individual não podem ser aplicados às ações coletivas, especialmente em tema de dano moral coletivo, constatandose que também quanto a tal matéria, havia uma carência de estudos pela doutrina trabalhista, para a qual a presente tese poderia apresentar sua contribuição.

Destarte, partiu-se da premissa de que os princípios do processo coletivo podem representar as diretrizes e os fundamentos necessários para que o juiz do Trabalho decida as complexas lides envolvendo danos morais coletivos e possa determinar uma indenização que seja capaz de propiciar uma efetiva reparação aos danos acarretados à coletividade de trabalhadores.

Por essas razões, os princípios do processo coletivo constituem o objeto do primeiro capítulo do presente trabalho, servindo como base de pesquisa o Anteprojeto de Código Brasileiro de Processos Coletivos e o Projeto de Lei $n^{\circ}$ 5.139/2009 (nova regulação da ação civil pública no Brasil), mas sem que fosse adotado como método, neste trabalho, o simples comentário dos princípios consagrados nessas propostas.

Constam desse primeiro capítulo os princípios que por sua peculiaridade ou aplicação diferenciada devem ser considerados como princípios do processo coletivo: o amplo acesso à Justiça, a economia processual, a publicidade com ampla divulgação dos atos processuais e a pacificação social, embora também sejam aplicados, com enfoques diferentes, em outros ramos do processo.

Por outro lado, o princípio da igualdade ou isonomia, por ser de caráter constitucional e aplicação geral, não foi indicado como princípio do processo coletivo, o 
mesmo ocorrendo com o princípio da boa-fé processual, pois a lealdade dos litigantes é exigível em qualquer ramo processual e não apresenta peculiaridades que possam justificar sua indicação como princípio próprio do processo coletivo.

Por sua vez, o princípio da máxima eficácia da tutela coletiva foi dividido em dois subprincípios, quais sejam, o princípio do interesse jurisdicional no conhecimento de mérito da ação coletiva, que direciona o juiz no sentido de sanar irregularidades e superar preliminares de forma a alcançar uma decisão de mérito, e o princípio da integral precaução, prevenção e reparação do dano coletivo, ponto central da presente tese.

Confirmou-se o princípio da prioridade de processamento do processo coletivo acrescentando-se a expressão "em todas as suas fases e instâncias", com o que pareceu desnecessário eleger-se a priorização da execução da sentença coletiva como princípio, além de justificar-se tal opção por ser a efetividade da execução um objetivo de qualquer processo, individual ou coletivo.

Por fim, foram indicados dois princípios não incluídos pelo Projeto de Lei $\mathrm{n}^{\circ}$ 5.139/2009, quais sejam, o princípio da relevância social que informa de maneira especial a tutela coletiva e o princípio da proporcionalidade e razoabilidade por ser imprescindível para as decisões que envolvem juízo de ponderação, próprio das ações coletivas, e, em especial, no arbitramento da indenização por dano moral coletivo.

Embora identificar princípios e discorrer sobre eles não seja uma tarefa simples, essa linha de pesquisa revelou-se uma opção acertada, pois representou a base sobre a qual se viabilizou o enfrentamento das questões relativas à efetividade da reparação do dano moral coletivo na Justiça do Trabalho.

Assim, apresentada a base principiológica a informar o processo coletivo, partiu-se para a estruturação do segundo capítulo quanto à reparação do dano moral coletivo, iniciando-se com uma análise comparativa entre o dano moral individual e o dano moral coletivo, no que se refere à base legal e evolução do conceito na doutrina e na jurisprudência.

Decisões trabalhistas consideradas como verdadeiros paradigmas nesse tema foram estudadas a fim de evidenciar que os juízes do Trabalho que participam ativamente do processo coletivo detêm melhores condições de identificar a mais adequada forma de reparação à coletividade lesada, inclusive pela percepção dos sentimentos da respectiva comunidade, aspecto de destaque na presente tese. 
Os princípios do processo coletivo são concretizados por meio dessas decisões da Justiça do Trabalho ainda que delas não constem de forma expressa, tal como identificado na presente tese, que também apontou os critérios que devem ser considerados pelos juízes para o arbitramento da indenização judicial, com base na doutrina e também na jurisprudência dos tribunais brasileiros.

O estudo da evolução do conceito de dano moral, do individual para o coletivo, foi fundamental para demonstrar que o caminho adotado era o correto, pois se não havia dúvidas quanto ao fim compensatório da indenização do dano moral individual, esse efeito era negado ou ignorado quanto ao dano moral coletivo, pela doutrina e também pela jurisprudência.

Foi necessário pesquisar sobre a regulação legal do Fundo de Amparo ao Trabalhador - FAT, os valores de recursos financeiros acumulados ao longo do tempo e a maneira como é feita a destinação desses recursos, inclusive por meio de um banco estatal, o Banco Nacional de Desenvolvimento Social - BNDES, para demonstrar a validade da tese quanto à inadequação desse destinatário frente à exigência de efetividade da reparação do dano moral coletivo.

A defesa da finalidade compensatória da indenização por dano moral coletivo acabou por ser um aspecto central na presente tese, sendo o tema desenvolvido com base nas disposições do próprio ordenamento jurídico e no estudo de direito comparado, pois em busca da efetividade da reparação invocou-se a experiência das class actions do direito norte-americano.

Com efeito, o estudo de um conceito construído pela jurisprudência das Cortes americanas, denominado como cy press ou fluid recovery e que não é estranho ao nosso meio jurídico, foi apresentado como opção para que o juiz do Trabalho possa invocar o direito comparado ao determinar uma forma de reparação que "seja o mais próxima possível" do dano acarretado à coletividade.

O aspecto pedagógico da indenização por dano moral coletivo não deixou de ser analisado sob a dupla perspectiva de envio ao Fundo de Amparo ao Trabalhador - FAT ou de uma reparação que pudesse beneficiar a coletividade lesada.

Foi objeto de destaque a experiência do Ministério Público do Trabalho como meio de demonstrar que outras formas de destinação para os valores decorrentes das indenizações por danos morais coletivos podem ser determinadas pelos juízes do Trabalho, 
mas não apenas pela via de homologação do acordo, sendo objeto de análise detalhada a questão dos limites do pedido formulado nas respectivas ações coletivas.

Outro aspecto da efetividade da reparação do dano moral coletivo não poderia deixar de ser examinado no presente trabalho: o papel do juiz, pois de sua atuação, dependeria, em última análise, a concretização da tese aqui defendida.

Assim, escreveu-se o terceiro capítulo com os olhos voltados para a figura do juiz e o papel que desempenhou ao longo do tempo, o qual se confunde com a própria evolução do Direito, demonstrando-se que uma postura ativa e participativa do magistrado, aliada à discricionariedade e criatividade no arbitramento da indenização por dano moral coletivo, são fundamentais para a efetividade da reparação do dano moral coletivo.

Por fim, apontou-se que outras medidas estão a merecer a atenção dos juristas do processo do trabalho e dos órgãos de administração do Judiciário, a fim de que o juiz possa ter as condições necessárias para se dedicar ao exame, à análise, à condução e à solução dos processos coletivos, apresentando-se algumas propostas nesse sentido.

Apresentada a conclusão, essa não poderia deixar de propor uma gradação quanto às formas de destinação mais apropriadas para a reparação do dano moral coletivo pelos juízes do Trabalho, de modo a representar uma contribuição sob o aspecto prático em prol do que se defende na presente tese: uma destinação que se mostre efetiva do ponto de vista da coletividade lesada e não apenas no aspecto de arrecadação de recursos para um fundo estatal desvinculado dessa finalidade. 


\section{CONCLUSÃO}

Há algumas escolhas que são feitas quando se realiza o estudo de um determinado tema, as quais marcam o desenvolvimento do trabalho em todas as suas fases e, no caso da presente tese, essa escolha recaiu sobre a questão da efetividade da indenização do dano moral coletivo na Justiça do Trabalho.

De plano, constatou-se que o envio para o Fundo de Amparo ao Trabalhador - FAT é a solução adotada pela jurisprudência trabalhista de forma majoritária, que assim decide com fulcro no pedido formulado nas ações coletivas e no disposto no artigo 13 da Lei $\mathrm{n}^{\circ}$ 7.347/85 - LACP, tendo o presente estudo como objetivo fundamentar alternativas a tal forma de destinação, que possam ser adotadas pelos juízes do Trabalho.

Para tanto, se mostrou imprescindível o estudo dos princípios do processo coletivo, pois são esses princípios que servirão de base para que o juiz do Trabalho possa superar o entendimento jurisprudencial dominante, o pedido que é feito nas ações coletivas e o próprio fundamento legal quanto à destinação da indenização a um fundo estatal, em prol de uma reparação efetiva do dano moral coletivo.

Em reforço, embora o Brasil conte com o microssistema formado pela Lei $\mathrm{n}^{\circ}$ 7.347/85 - LACP e Lei $n^{\circ}$ 8.078/90 - CDC e existam projetos de codificação do processo coletivo, especialmente o Projeto de Lei $n^{\circ} 5.139 / 2009$, que representaria avanço positivo na regulação das ações coletivas, não se tem muitas expectativas quanto à sua aprovação, o que não impede que muitas das suas inovações possam ser adotadas pelos juízes do Trabalho, pois fundamentadas nos princípios do processo coletivo.

Nessa linha, foi realizado um estudo aprofundado dos princípios que regem o processo coletivo, defendendo-se que nos litígios que envolvem interesses e direitos de natureza transindividual sejam aplicados princípios próprios desse ramo do processo, representando o presente estudo uma contribuição a respeito desse complexo tema, ainda pouco explorado pela doutrina trabalhista.

Destacou-se, inicialmente, que a importância e o papel dos princípios do Direito tiveram enfoques diversos nos movimentos conhecidos como jusnaturalismo, positivismo e pós-positivismo, sendo esse último marcado pela positivação e constitucionalização dos 
princípios, de maneira que tanto a lei como as decisões judiciais devem estar em conformidade com os princípios.

Os princípios gerais do processo sempre exigiram da doutrina um esforço de interpretação para que fossem deduzidos de regras mais gerais das Constituições brasileiras, esforço que pouco repercutia na jurisprudência, sendo esse cenário alterado significativamente com o advento da Constituição de 1988, pois os princípios passaram a constar de disposições expressas, formando um rol das garantias constitucionais do processo.

Princípios do acesso à Justiça, do devido processo legal, da igualdade, do contraditório, da motivação das decisões judiciais, da publicidade e da duração razoável do processo formaram a base principiológica constitucional da qual foram extraídos os princípios do processo coletivo apontados no decorrer do presente estudo que se valeu, também, das propostas de codificação do processo coletivo e, especialmente, do disposto no artigo $3^{\circ}$. do Projeto de Lei $n^{\circ} 5.139 / 2009$.

Os princípios constitucionais de acesso à Justiça e do devido processo legal são considerados na presente tese como "princípios balizas", pois deles decorrem ou defluem os princípios que regem o processo coletivo, constituindo os fundamentos de que pode se valer o juiz do Trabalho para garantir a efetividade da reparação do dano moral coletivo.

A presente tese apontou os seguintes princípios do processo coletivo: o amplo acesso à Justiça; a participação social; a economia processual; a adequação e flexibilidade procedimental e a máxima efetividade, além dos princípios que decorrem desse último, quais sejam, o princípio do interesse jurisdicional no conhecimento de mérito da ação coletiva e o princípio da integral precaução, prevenção e reparação do dano coletivo, sendo esse de destacada importância para a tese aqui defendida.

Foram ainda listados como princípios do processo coletivo: a motivação adequada ou específica da decisão judicial; a publicidade e a ampla divulgação dos atos processuais; a prioridade de tramitação do processo coletivo em todas as fases e instâncias; a pacificação social; a colaboração ou cooperação; a relevância social e a proporcionalidade e razoabilidade.

Assim, o que a presente tese propõe é uma base principiológica em prol da efetividade da reparação do dano moral coletivo, mas que será insuficiente se o juiz do Trabalho não assumir uma participação ativa no processo e não usar de sua 
discricionariedade e criatividade para fixar uma indenização que beneficie a coletividade lesada.

Discricionariedade e criatividade judicial são aqui defendidas com base nos princípios da relevância social da tutela coletiva e, em especial, no princípio da proporcionalidade e razoabilidade na fixação do valor da indenização, com objetivo de alcançar o equilíbrio necessário entre a reparação e o dano, por meio dos seguintes critérios: a capacidade econômica do ofensor; a natureza e a gravidade da lesão; a ocorrência de culpa ou dolo na prática do ilícito e a reiterada ofensa ou sua reincidência.

Novo critério consistente na punição do ofensor pelo enriquecimento sem causa foi previsto pelo artigo $3^{\circ}$. do Projeto de Lei $\mathrm{n}^{\circ}$ 5.139/2009 como integrante do princípio da tutela coletiva adequada para a efetiva precaução, prevenção e reparação do dano moral individual e coletivo, de forma a consagrar o efeito punitivo para o ofensor que aufere benefícios econômicos à custa da lesão aos interesses e direitos transindividuais.

O enriquecimento sem causa constitui importante fundamento para o dumping social, admitido por parte doutrina e de forma minoritária pela jurisprudência trabalhista, mas de acordo com a tese aqui defendida não poderá acarretar uma condenação em separado e em acréscimo pelo dano moral coletivo, devendo ser considerado como agravante do ilícito e servir de fundamento para a majoração da respectiva indenização.

O dano moral coletivo, tal como o dano individual da mesma natureza, é indenizado por arbitramento judicial que exige bom senso e prudência do juiz, alcançados mediante ponderação entre os critérios acima apontados e as peculiaridades do caso concreto, não sendo possível adotar o legislador uma prévia tarifação, por incompatibilidade com o disposto no artigo $5^{\circ}$, inciso V, da Constituição.

Ainda com relação aos critérios, destaca-se que o dano moral coletivo não corresponde à somatória dos danos morais individuais, razão pela qual a respectiva indenização não deve ser arbitrada considerando-se valores individuais, como o número de empregados e valor de salário, mas sim com base nos critérios acima apontados e considerando-se a extensão e a gravidade do dano para a comunidade.

Isso porque o dano moral coletivo repercute em uma classe, categoria ou comunidade de pessoas e é sempre global e indivisível, ainda que se possa vislumbrar do fato que o originou um dano aos indivíduos, que será de natureza divisível e poderá ser 
postulado por meio de uma reclamação individual ou por meio de uma ação coletiva, se caracterizada a homogeneidade da pretensão.

Observou-se que os "sentimentos" estiveram na origem dos debates sobre a possibilidade de indenizar-se o dano moral individual, sendo viabilizada a reparação a partir da superação do argumento de não ser possível "colocar preço na dor", o que não impede que sentimentos como desapreço, humilhação e indignidade sejam frequentemente referidos pelos juízes no arbitramento da reparação individual.

Da mesma forma, embora não seja possível a comprovação quanto aos sentimentos da coletividade que foi lesada em seus valores, defende-se que o juiz do trabalho considere o "sentir coletivo", na forma de indignação, repúdio ou consternação social, referidos pela jurisprudência trabalhista e que poderão ser considerados na ponderação de critérios e juízo de razoabilidade para fixação da respectiva indenização.

Não obstante se reconheça que não é tarefa simples alcançar-se a percepção da coletividade quanto à reparação do dano moral coletivo, ao contrário do que ocorre com o dano moral individual, poderá o juiz adotar medidas para divulgação da respectiva decisão judicial, devendo observar a devida clareza e simplicidade, com fundamento nos princípios da ampla publicidade, participação social e motivação adequada ou específica do processo coletivo.

Apenas um juiz que assuma a condução ativa do processo coletivo no qual seja postulada a reparação do dano moral coletivo, em participação não apenas com as partes, mas também com a comunidade prejudicada, terá condições de decidir sobre a melhor forma de reparação, de forma a concretizar o princípio da máxima efetividade judicial e o princípio da integral precaução, prevenção e reparação desse dano.

A presente tese defende a premissa que a indenização do dano moral coletivo, tal como ocorre com o dano moral individual, deve primar pelo tríplice efeito da reparação, representando a punição para o ofensor, como também o fim pedagógico para toda a sociedade e a compensação para a coletividade prejudicada.

Foi dedicada especial atenção ao efeito compensatório da indenização por dano moral coletivo, não admitido pela doutrina ou pela jurisprudência dos tribunais brasileiros, defendendo-se ser imprescindível que se alcance tal finalidade, de maneira que a indenização beneficie a coletividade e represente também uma satisfação para aquele "sentir coletivo" de injustiça social. 
Embora se reconheça que reparação in natura constitui exceção em matéria de dano moral coletivo e que uma compensação à comunidade jamais poderá obter a plena equivalência entre reparação e prejuízo acarretado, demonstrou-se que as lições do direito comparado podem trazer alguma luz para a questão da falta de efetividade da reparação no nosso sistema.

Foi da década de 70 do século XX que advogados atuantes nas class actions invocaram perante as Cortes dos EUA o precedente do cy pres, até então próprio do direito civil, nos casos em que remanescia valor no fundo criado para ressarcimento das vítimas do dano coletivo, com base na tese de aplicação desses recursos "o mais perto do possível" da natureza do dano e daqueles que foram prejudicados.

Em defesa dessa alternativa invocavam um argumento de equidade, pois não parecia justo que valores que remanesciam no fundo acabassem sendo devolvidos ao réu ou fossem destinados aos cofres públicos, no lugar de beneficiar, de alguma forma, aqueles que sofreram mais de perto os prejuízos, solução denominada de reparação cy pres ou fluid recovery.

Reportou-se que a reparação na forma de fluid recovery, expressão consagrada pela doutrina brasileira, fora adotada pelo artigo 100, parágrafo único, da Lei $n^{\circ}$ 8.078/90 CDC, também para a hipótese de o número de habilitados individualmente ser desproporcional ao dano coletivamente considerado, tal como ocorre com as class actions no sistema norte-americano.

O estudo de direito comparado viabilizou o fundamento, aqui defendido, de que deve o juiz buscar uma forma de reparação que estabeleça uma conexão mais próxima com o dano, a "mais próxima do possível", do tipo cy pres ou fluid recovery das class actions do direito norte-americano, inclusive para proporcionar uma satisfação àquele sentimento da coletividade lesada.

Na sequência foi empreendida pesquisa sobre a origem, a finalidade, os objetivos e os valores que são arrecadados anualmente pelo Fundo de Amparo ao Trabalhador FAT, confirmando-se que esse fundo tem como objetivos custear os benefícios do segurodesemprego e abono salarial, além de financiar a atividade produtiva, por meio do Banco Nacional de Desenvolvimento Social - BNDES, contando, para tanto, com recursos garantidos pela Constituição. 
Confirmou-se, assim, que o Fundo de Amparo ao Trabalhador - FAT não tem entre seus objetivos institucionais a aplicação de recursos na reparação dos danos morais coletivos reconhecidos pela Justiça do Trabalho, não existindo informações claras sobre o destino dado a tais recursos nas suas demonstrações financeiras, além de serem frequentes as denúncias de desvio de verbas aplicadas pelo Banco Nacional de Desenvolvimento - BNDES.

É verdade que a destinação dos recursos incumbe a um conselho, no caso ao CODEFAT, mas não foi assegurada a participação do Ministério Público do Trabalho, ao contrário do que ocorre com o Fundo de Direitos Difusos previsto pelo artigo 13 da Lei $\mathrm{n}^{\circ}$ $7.347 / 85$, que assegura a representação e participação do parquet.

Coincidência ou não, foi o Ministério Público do Trabalho que primeiro se deu conta da falta de conexão entre a reparação e o dano moral coletivo, adotando formas alternativas em benefício da coletividade, de maneira a realizar, na atualidade, as mais variadas destinações que são autorizadas pelos seus órgãos internos de fiscalização.

Diante desse quadro, concluiu-se que não é possível alcançar qualquer efeito de compensação à coletividade, exigido pelo princípio da integral reparação do dano, com a destinação do valor da indenização por dano moral coletivo para o Fundo de Amparo ao Trabalhador - FAT, o que legitima a invocação do direito comparado, como forma de suprir a omissão do legislador, nos termos do artigo $8^{\circ}$. da Consolidação das Leis do Trabalho - CLT.

No que se refere ao efeito pedagógico da reparação, deve a decisão repercutir na sociedade a fim de prevenir outras lesões, de acordo com o princípio da máxima precaução e prevenção do dano, o que também não se concretiza com a remessa para o Fundo de Amparo ao Trabalhador - FAT, pois nesse caso não haverá qualquer percepção da coletividade quanto à existência de condenação pelo dano moral coletivo.

O que se concluiu é que a remessa do valor da indenização por dano moral coletivo para o Fundo de Amparo ao Trabalhador - FAT alcança apenas o efeito punitivo para o ofensor e que alternativas a essa forma de destinação podem ser mais interessantes, por possibilitar o envolvimento do ofensor na atividade prática de reparação dos prejuízos acarretados à comunidade na qual, em regra, está também inserido, medida que encontra respaldo nos princípios da participação social e colaboração. 
Registra-se, ainda, que ao contrário do que referido pela doutrina de forma quase uníssona, não há semelhanças entre o fundo comum ao grupo (common fund) oriundo de uma class action e o fundo de natureza difuso previsto pela Lei $\mathrm{n}^{\circ} 7.347 / 85$ - LACP, pois no sistema norte-americano o fundo é criado para um determinado processo, com valores que ficam a ele vinculados e para reparação dos respectivos danos acarretados às vítimas.

O mais significativo, entretanto, é que o sistema brasileiro de envio de valores a um fundo estatal acabou por afastar o juiz da causa do acompanhamento da respectiva destinação e de possibilitar a evolução da jurisprudência nessa matéria, pois os juízes têm por cumprido seu papel com a publicação da decisão judicial e posterior remessa de valores ao Fundo de Amparo ao Trabalhador - FAT.

Sem dúvida que a criação de um fundo geral para a reparação de danos acarretados à coletividade de trabalhadores, ou mesmo fundos específicos, como os destinados a fomentar o trabalho decente ou combater as piores formas de exploração do trabalho humano, representariam um avanço significativo para a maior efetividade da reparação desse tipo de dano.

Por outro lado, ainda que no futuro lei disponha sobre a criação desses fundos, incumbirá ao juiz do Trabalho decidir sobre a melhor forma de reparação, para concretizar os efeitos compensatório, pedagógico e punitivo da indenização, com fulcro no princípio da relevância social da tutela e princípio da integral precaução, prevenção e reparação do dano moral coletivo.

Esses princípios legitimam, inclusive, a decisão que determinar o depósito da condenação em pecúnia à disposição do juízo, ao qual incumbirá decidir sobre a melhor forma de destinação para a recuperação ou compensação “o mais próxima do possível” dos danos morais coletivos, com a participação dos interessados por meio da audiência pública e acompanhamento do Ministério Público do Trabalho, tal como previsto pelo artigo 45, parágrafos $1^{\circ}$ e $2^{\circ}$, do Projeto de Lei n ${ }^{\circ} 5.139 / 2009$.

Poderá o juiz do Trabalho invocar, como reforço de fundamentação, o disposto no artigo $5^{\circ}$, inciso $\mathrm{V}$, da Constituição, que dispõe sobre a reparação do dano proporcional ao agravo, bem como que a reparação deve considerar a extensão do dano (artigo 944 do Código Civil) e sua efetiva prevenção e reparação (artigo $6^{\circ}$, inciso IV, da Lei $\mathrm{n}^{\circ}$ 8.078/90 - CDC), o que importa considerar os efeitos compensatório e pedagógico da indenização, que somente serão alcançados se a destinação observar uma necessária conexão entre a 
destinação e a natureza do dano (artigo 13 da Lei no 7.347/85 - LACP; artigo $1^{\circ}$, parágrafo $3^{\circ}$, da Lei ${ }^{\circ} 9.008 / 95$ e artigo $7^{\circ}$. do Decreto $\left.n^{\circ} 1.306 / 94\right)$.

A presente conclusão não estaria completa se não apresentasse uma proposta contendo uma gradação que pudesse servir de referência para o juiz do Trabalho que decida direcionar a indenização em benefício da própria coletividade de trabalhadores lesada pelo dano de natureza imaterial:

1. Em benefício da própria coletividade lesada - programas e cursos de capacitação profissional; entrega de veículos para transporte seguro na área rural; creches para os filhos dos trabalhadores; programas de prevenção de acidentes; construção e manutenção de espaços de convívio e lazer; campanhas educativas sobre não discriminação no trabalho; combate ao trabalho escravo e de crianças e adolescentes;

$\mathbf{2}^{\mathbf{a}}$. Destinação às entidades governamentais ou da sociedade civil que tenham programas voltados para a proteção dos trabalhadores ou promoção de seus direitos, de âmbito municipal, regional ou nacional, de acordo com a natureza e a extensão do dano, como os projetos de combate ao trabalho escravo e de propagação do trabalho decente;

$3^{\text {a }}$. Benefícios para a comunidade em que estão inseridos os trabalhadores, como escolas, casas de repouso e hospitais que prestem atendimento para a respectiva comunidade, apenas no caso das duas anteriores não se mostrarem mais adequadas para reparar o dano coletivo.

É importante esclarecer que a gradação ora proposta é apenas uma referência e, em razão dos múltiplos aspectos envolvendo os danos morais coletivos, poderá ser totalmente invertida, como nos casos de danos acarretados à saúde e higidez física dos trabalhadores, quando a destinação para o hospital do local do dano será muito mais efetiva do que a implantação de cursos de capacitação ou treinamento.

Em razão da gradação acima proposta justifica-se a posição contrária ao envio de valores decorrentes da indenização por dano moral coletivo a entidades de caridade como regra geral, pois essa destinação não alcançará a finalidade compensatória da reparação, pela falta de conexão com a lesão perpetrada aos bens de natureza imaterial dos trabalhadores.

Em acréscimo, é imprescindível que se observe o princípio da publicidade e da ampla divulgação dos atos processuais para que sejam concretizados os efeitos 
compensatório e pedagógico na prática, o que não será alcançado se a instituição e a respectiva comunidade não forem cientificadas sobre as razões da condenação por dano moral coletivo.

É verdade que o envio de valores a instituições assistenciais também é adotada nas class actions do direito norte-americano, com fundamento na cy pres ou fluid recovery, mas também é certo que a medida é alvo de várias críticas, sob o fundamento de desvios, conluio ou benefícios indiretos, risco já antevisto pelo Ministério Público do Trabalho, que não recomenda destinação em seu próprio benefício ou aos órgãos de fiscalização.

A possibilidade de remessa de valores a um fundo estatal não é totalmente descartada pelo presente estudo, mas é considerada apenas na impossibilidade de uma reparação em benefício da coletividade lesada, ou como destinatário de multas aplicadas nas ações coletivas, portanto, como medida supletiva, tal como dispõe o artigo 65 , parágrafo único, do Projeto de Lei no 5.139/2009.

Não se poderia deixar de enfrentar a questão do pedido formulado nas ações coletivas e que indica o Fundo de Amparo ao Trabalhador - FAT como destinatário da indenização por dano moral coletivo, demonstrando que o juiz do Trabalho que determinar outra forma de reparação não estaria julgando extra petita.

E isso porque o pedido a ser julgado é de reparação do dano moral coletivo e é esse que vincula o juiz do Trabalho e não a indicação do destinatário, que pode ou não constar da petição inicial, pois deve ainda ser considerada a autorização legal para a dedução de pedido genérico, em razão da própria natureza da pretensão.

Em acréscimo, deve ser considerada a ausência de prejuízo para as partes, Autor ideológico e Réu, na determinação que destina o valor da indenização em benefício da coletividade lesada e não ao Fundo de Amparo ao Trabalhador - FAT e, portanto, não decorre dessa decisão qualquer nulidade.

A decisão que remete o valor da indenização por dano moral coletivo para o Fundo de Amparo ao Trabalhador - FAT se afasta, ainda, do princípio do amplo acesso à Justiça, que na atualidade não mais se satisfaz com a garantia de acesso ao Judiciário, ao contrário, é a efetividade do provimento a condição para que tal princípio seja realmente concretizado. 
Destaca-se a importância do princípio da motivação adequada em face da sentença que arbitra o valor da indenização por dano moral coletivo e indica a forma mais adequada da reparação, pois o juiz deverá demonstrar o raciocínio utilizado, os critérios que ponderou e aplicou, de acordo com o princípio da proporcionalidade e razoabilidade e as peculiaridades do caso concreto.

O princípio da motivação adequada concretiza a garantia de imparcialidade do juiz, legitima a discricionariedade e criatividade judicial além de viabilizar o controle judicial pelos Tribunais Superiores que admitem a revisão da decisão que se afaste dos critérios apresentados para o respectivo arbitramento judicial.

A sentença que decide sobre o conflito coletivo concretiza o princípio do interesse jurisdicional no conhecimento de mérito da ação coletiva, o que significa envidar esforços para evitar a extinção prematura da ação, superar vícios e irregularidades, com base no princípio da adequação e flexibilidade procedimental, atuação que é legitimada pela relevância social da respectiva tutela.

Não há dúvida de que essa atuação do juiz não será isolada, pois sem a colaboração das partes, imbuídas do mesmo propósito de se alcançar uma sentença de mérito, capaz de solucionar em definitivo a questão controversa e difundir a pacificação social, nada ou muito pouco poderá ser efetivado pela decisão judicial, defendendo-se, inclusive que as próprias partes participem e apresentem propostas quanto à melhor forma de reparação dos danos morais coletivos.

Por essa razão, a colaboração é apontada como princípio capaz de, verdadeiramente, impulsionar uma mudança de cultura do processo, que não pode mais ser considerado como "uma luta" na qual deve se dar a garantia de "paridade de armas" às partes, concepção que alimenta uma litigiosidade praticamente enraizada na cultura jurídica do país.

A participação ativa do juiz no processo coletivo é imprescindível para que sejam concretizados os princípios da colaboração e da pacificação social, pois dos seus atos dependerá uma nova motivação para que as partes atuem em colaboração com o juízo e, ainda, é a decisão judicial que poderá ou não concretizar o objetivo de pacificação social.

Não se deve ser ingênuo a ponto de pensar que a colaboração, reconhecida como princípio pelo direito estrangeiro e nas propostas de reforma da codificação processual no Brasil, possa sempre ser conquistada entre os vários envolvidos num conflito coletivo, mas 
é possível iniciar-se uma mudança de perspectiva no processo coletivo do trabalho, incentivando-se que todos participem e deem a sua contribuição para a melhor solução da lide.

A economia processual pode ser um argumento que incentive as partes a atuar em colaboração com o juízo, pois a economia tem um enfoque diferente no processo coletivo, no qual se expande para além do processo, já que uma única decisão pode prevenir o ajuizamento de diversas ações individuais acarretando maiores custos para todos os envolvidos.

Não se deixou de considerar que o processo coletivo exigirá a prática de numerosos e complexos atos processuais e que a economia deverá ser vista do ponto de vista do sistema judicial como um todo e da própria sociedade, como instrumento capaz de reduzir o imenso contingente de "demandas repetitivas" que são distribuídas todos os anos no Judiciário brasileiro.

Para que tal finalidade seja alcançada, deverá ser observado o princípio da prioridade de tramitação da ação coletiva em todas as fases e instâncias, pois somente com essa medida será possível prestigiar-se a sentença das demandas "moleculares" que podem não apenas reparar os danos coletivos, mas ter o efeito de impedir que se perpetuem e se agravem com o tempo.

A priorização das demandas coletivas pode ser administrada pelo próprio juiz do Trabalho por meio da inclusão desses processos em pautas de audiência e de julgamento, com fundamento no princípio do amplo acesso à Justiça, da economia processual, e da relevância social da tutela, embora não se possa deixar de reconhecer que essa medida teria seu efeito potencializado, se tomada como decisão de administração judiciária dos Tribunais.

Por outro lado, se o esforço do juiz em prolatar uma decisão adequada às peculiaridades das ações coletivas, bem como em fiscalizar e acompanhar a correta destinação da indenização do dano moral coletivo, não for devidamente valorizado, muito pouco será alterado do quadro existente de desprestígio dessas ações no Judiciário brasileiro.

Bastaria que se apontasse a questão da equivalência numérica nas estatísticas de produtividade entre ações individuais e ações coletivas para restar justificada a assertiva de que o juiz não tem qualquer razão para dedicar o seu tempo e o seu trabalho na busca de 
uma solução justa e efetiva do processo coletivo, se for cobrado e avaliado de acordo com o número de ações individuais que conseguir solucionar.

A questão da capacitação de juízes em matéria de processos coletivos e de técnicas de conciliação e mediação de conflitos coletivizados foi destacada como imprescindível para uma mudança de foco, pois a maior parte dos juízes do Trabalho teve formação e atua de forma preponderante em reclamações trabalhistas que refletem os chamados conflitos "atomizados".

Não se compartilha do entusiasmo daqueles que defendem a criação de unidades judiciárias especializadas em processos coletivos como medida de economia e celeridade processuais, pois essa centralização comprometeria o princípio da participação social, sendo o juiz da comunidade na qual ocorreu o dano, o que detêm melhores condições de apreender aquele "sentir coletivo", de maneira a atuar em prol da pacificação social do conflito.

Defende-se, por outro lado, que parcerias sejam feitas pelo Judiciário Trabalhista visando auxiliar o juiz no processo coletivo, pois esse exigirá provas técnicas complexas, além da prestação de serviços de auxiliares do juízo, inclusive para a implementação e fiscalização da destinação da indenização do dano moral coletivo, devendo ser priorizado um diálogo permanente com o Ministério Público do Trabalho.

Constatou-se a omissão da participação de juristas do direito do trabalho nas iniciativas de aperfeiçoamento e codificação do processo coletivo, o que deveria ser revertido, pois embora esses projetos contenham inúmeros avanços, teriam que ser necessariamente adaptados ao processo do trabalho, acarretando grandes dificuldades para os juízes, aliás, como já ocorre com relação à aplicação do microssistema de processos coletivos.

Somente contando com o papel ativo e criativo dos juízes do Trabalho na aplicação dos princípios do processo coletivo e com a valorização e aperfeiçoamento do trabalho dos magistrados, poderá ser alcançado o objetivo de reparação efetiva do dano moral coletivo acarretado à coletividade dos trabalhadores brasileiros.

Assim, a presente tese pretende, por fim e depois de tudo bem ponderado, impulsionar uma reflexão sobre os efeitos que devem ser alcançados pelas condenações por danos morais coletivos na Justiça do Trabalho, lançando luz para o fato de que o envio 
do respectivo valor para o Fundo de Amparo aos Trabalhadores - FAT representa apenas o restrito efeito punitivo para o ofensor.

A coletividade de trabalhadores que é lesada em seus valores e direitos imateriais merece muito mais do que isso. Merece ter uma reparação que represente uma compensação "o mais próxima do possível” em face dos danos sofridos e que possa também ter o efeito pedagógico para toda a sociedade em defesa dos direitos sociais.

E, para tal mudança, será fundamental considerar-se o papel do juiz do Trabalho e a aplicação dos princípios do processo coletivo.

É o que se defende e se espera ter contribuído com a presente tese. 


\section{REFERÊNCIAS}

ABRAMOVICH, Víctor; COURTIS, Christian. Los derechos sociales como derechos exigibles. Madrid: Editorial Trotta, 2002.

ALEXY, Robert. Teoría de la argumentación jurídica. Trad.de M.Atienza e I. Espejo. Madrid: Centro de Estudos Constitucionais, 1989.

Teoria de los derechos fundamentales. 2 reimpr. Madrid: Centro de Estudios Politicos y Constitucionales, 2001.

ALMEIDA, Gregório Assagra de. Codificação do direito processual coletivo brasileiro: análise crítica das propostas existentes e diretrizes para uma nova proposta de codificação. Belo Horizonte: Del Rey, 2007.

Direito processual coletivo brasileiro: um novo ramo do direito processual. São Paulo: Saraiva, 2003.

ALMEIDA, Marcos Antônio Ferreira. A efetividade da reparação do dano moral coletivo na Justiça do Trabalho. Revista do Ministério Público do Trabalho, Procuradoria-Geral do Trabalho, ano 20, n. 39, mar. 2010. Disponível em: <http://fs1.anpt.org.br/aux1/2011/45/anpt1149708849286.pdf>. Acesso em: 26 set. 2013.

ALMEIDA, Tania. Mediação e conciliação: dos paradigmas distintos, duas práticas diversas. In: CASELLA, Paulo Borba; SOUZA, Luciane Moessa de (Coords..). Mediação de conflitos: novo paradigma de acesso à justiça. Belo Horizonte: Fórum, 2009.

ALVES, Alaôr Caffé. Apresentação à edição brasileira. In: ROSS, Alf. Direito e justiça. Trad. Edson Bini, rev. téc. Alysson Leandro Mascaro. 1. reimpr. Bauru (SP): EDIPRO, 2003.

ALVIM, Agostinho. Da inexecução das obrigações e suas consequências. 5. ed. São Paulo: Saraiva, 1980.

ANDRADE, André Gustavo Corrêa de. Dano moral e indenização punitiva. Rio de Janeiro: Forense, 2006.

ARENDT, Hannah. Responsabilidade e julgamento. Trad. Rosaura Einchenberg. São Paulo: Companhia das Letras, 2004. Título original: Responsability and Judgement. 
ASSIS, Luis Fabiano de. Ativismo judicial na Justiça do Trabalho. 2011. Tese (Doutorado em Direito) - Faculdade de Direito, Universidade de São Paulo, 2011.

ATIENZA, Manuel. As razões do direito: teorias da argumentação jurídica. Trad. de Maria Cristina Guimarães Cupertino. 3. ed. São Paulo: Landy, 2003.

AUGUSTIN, Sérgio; ALMEIDA, Ângela. A indefinição jurisprudencial em face do dano moral coletivo. Disponível em: $<$ http://www.google.com.br/url?sa=t\&rct=j\&q=\&esrc=s\&source=web\&cd=1\&ved=0CC4 QFjAA\&url=http\%3A\%2F\%2Fwww.enm.org.br\%2Fdocs\%2Fbiblioteca\%2FDano\%2520 moral\%2520coletivo\%2520-

\%2520Revista\%2520eletr\%25C3\%25B4nica\%2520ENM.doc\&ei=ebAnUpu_LIfs8QSmYGYAw\&usg=AFQjCNGubQ89cjY2fb60JDp1cbztxO8F3A>. Acesso em: 04 set. 2013.

ÁVILA, Humberto. Teoria dos princípios: da definição à aplicação dos princípios jurídicos. 7. ed. São Paulo: Malheiros, 2007.

AZEVEDO, André Gomma de. Fatores de efetividade de processos de resolução de disputas: uma análise sob a perspectiva construtivista. In: CASELLA, Paulo Borba; SOUZA, Luciane Moessa de (Coords.). Mediação de conflitos: novo paradigma de acesso à justiça. Belo Horizonte: Fórum, 2009.

(Org.). Manual de Mediação Judicial (Brasília/DF: Ministério da Justiça e Programa das Nações Unidas para o Desenvolvimento - PNUD, 2013). Disponível em: <http://www.cnj.jus.br/images/programas/conciliacao/manual_mediacao_judicial_4ed.pdf > . Acesso em: 06 nov. 2013.

AZEVEDO JÚNIOR, José Osório de. O dano moral e sua avaliação. Disponível em: $<$ http://www.buscalegis.ufsc.br/revistas/files/anexos/6990-6989-1-PB.htm>. Acesso em: 23 ago. 2013.

BANDEIRA DE MELLO, Celso Antonio. Curso de direito administrativo. São Paulo: Malheiros, 1994.

. Discricionariedade administrativa e controle jurisdicional. 2. ed. 3. tir. São Paulo: Malheiros, 1998.

BARBOSA, Maria da Graça Bonança. Ação coletiva trabalhista: novas perspectivas. São Paulo: LTr, 2010. 
BARBOSA MOREIRA, José Carlos. A motivação das decisões judiciais como garantia inerente ao Estado de direito. In: BARBOSA MOREIRA, José Carlos. Temas de direito processual: 2. série. 2. ed. São Paulo: Saraiva, 1988.

- Os poderes do juiz na direção e na instrução do processo. In: BARBOSA MOREIRA, José Carlos. Temas de direito processual: 4. série. São Paulo: Saraiva, 1989.

A proteção jurídica dos interesses coletivos. In: BARBOSA MOREIRA, José Carlos. Temas de direito processual civil: $3^{\mathrm{a}}$ série. São Paulo: Saraiva, 1984.

. Reformas processuais e poderes do juiz. In: BARBOSA MOREIRA, José Carlos. Temas de direito processual civil: 8 a série. São Paulo: Saraiva, 2004.

- Tutela jurisdicional dos interesses coletivos ou difusos. In: BARBOSA MOREIRA, José Carlos. Temas de direito processual civil: $3^{\mathrm{a}}$ série. São Paulo: Saraiva, 1984.

BARCELOS, Ana Paula de. A eficácia jurídica dos princípios constitucionais: o princípio da dignidade da pessoa humana. Rio de Janeiro: Renovar, 2002.

BARROSO, Luís Roberto; BARCELLOS, Ana Paula de. A nova interpretação constitucional: ponderação, argumentação e papel dos princípios. In: LEITE, George Salomão (Coord.). Dos princípios constitucionais: considerações em torno das normas principiológicas da Constituição. São Paulo: Malheiros, 2003.

BASTOS, Celso S. Ribeiro. Hermenêutica e interpretação constitucional. 3. ed. São Paulo: Celso Bastos, 2002.

BATAlHA, Wilson de Souza Campos. Tratado de direito judiciário do trabalho. 3. ed. rev., atual. e ampl. São Paulo: LTr, 1995.

BEDAQUE, José Roberto dos Santos. Direito e processo: influência do direito material sobre o processo. 3. ed., rev.e ampl. São Paulo: Malheiros, 2003.

Efetividade do processo e técnica processual. 3. ed. São Paulo: Malheiros, 2010.

Tutela cautelar e tutela antecipada: tutelas sumárias e de urgência (tentativa de sistematização). 5. ed. rev. e ampl. São Paulo: Malheiros, 2006.

BESSA, Leonardo Roscoe. Dano moral coletivo. Disponível em: <www.mpba.mp.br/atuacao/ceacon/doutrina/dano_moral_coletivo.pdf $>$. Acesso em: 26 ago. 2013. 
BITTAR, Carlos Alberto. Reparação civil por danos morais. 2. ed. São Paulo: Revista dos Tribunais, 1994.

BITTAR FILHO, Carlos Alberto. Do dano moral coletivo no atual contexto jurídico brasileiro. Revista de Direito do Consumidor, São Paulo, n. 12, out./dez. 1994.

BOBBIO, Norberto. A era dos direitos. Trad. de Carlos Nelson Coutinho. 18. tir. Rio de Janeiro: Campus, 1992.

Locke e o direito natural. Trad. de Sérgio Bath. Brasília, DF: Universidade de Brasília, 1997.

O positivismo jurídico: lições da filosofia do direito. Compilação: Nello Morra; trad. e notas Márcio Pugliesi, Edson Bini, Carlos E. Rodrigues. São Paulo: Ícone, 1995.

Teoria da norma jurídica. Trad. Fernando Pavan Baptista e Ariani Bueno Sudatti. Bauru, SP: EDIPRO, 2001.

. Teoria do ordenamento jurídico. Trad. Maria Celeste C. J. Santos. Brasília, DF: Universidade de Brasília, 1999.

BONAVIDES, Paulo. Curso de direito constitucional. 8. ed. São Paulo: Malheiros, 1998.

BONÍCIO, Marcelo José Magalhães. Proporcionalidade e processo. a garantia constitucional da proporcionalidade, a legitimação do processo civil e o controle das decisões judiciais. 1. ed. São Paulo: Atlas, 2006. (Coleção Atlas de Processo Civil Coordenação Carlos Alberto Carmona).

BRASIL, Ávio. O dano moral no direito brasileiro. Rio de Janeiro: Livraria Jacinto, 1944.

CAHALI, Yussef Said. Dano moral. 3. ed. rev., ampl. e atual. São Paulo: Revista dos Tribunais, 2005.

CANOTILHO, J.J. Gomes. Direito constitucional. 3. ed. reimpr. Coimbra: Almedina, 1999.

CAPPELlETTI, Mauro. Formações sociais e interesses coletivos diante da justiça civil. Revista de Processo, São Paulo, n. 5, p. 128-149, 1977.

Juízes legisladores? Trad. Carlos Alberto Álvaro de Oliveira. Porto Alegre: Sérgio A. Fabris Editor, 1993. 
CAPPELLETTI, Mauro. Juízes legisladores? Trad. Carlos Alberto Alvaro de Oliveira. Porto Alegre: Sérgio Fabris Editor, 1999.

; GARTH, Bryant. Acesso à justiça. Trad. e rev. de Ellen Graice Northfleet. Porto Alegre: Sergio Antonio Fabris, 1988. Título original: Access to justice: the worldwide movement to make rights effective - a general report. Millan, 1978.

CARELLI, Rodrigo de Lacerda. Transação na ação civil pública e na execução do termo de ajustamento de conduta e a reconstituição dos bens lesados. Revista do Ministério Público do Trabalho, Brasília, n. 33, mar. 2007.

CARRION, Valentin. Comentários à Consolidação das Leis do trabalho. 26. ed. atual. e ampl. por Eduardo Carrion. São Paulo: Saraiva, 2001.

CAVAlIERI FILHO, Sérgio. Programa de responsabilidade civil. 6. ed. São Paulo: Malheiros, 2005.

CERDEIRA, Eduardo de Oliveira. A execução/cumprimento de sentença no processo coletivo. Revista LTr, São Paulo, v. 72, n. 12, p. 1463-1476, dez. 2008.

CHIAVARIO, Mario. Processo e garanzie della persona. Milano: Giufré, 1982. v. 1 e v. 2.

CINTRA, Antonio Carlos de Araújo; GRINOVER, Ada Pellegrini; DINAMARCO, Cândido Rangel. Teoria geral do processo. São Paulo: Revista dos Tribunais, 1974.

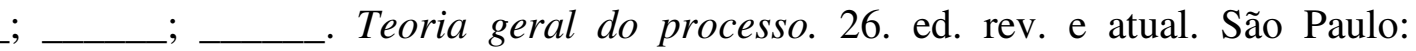

Malheiros, 2010.

COMPARATO, Fábio Konder. A afirmação histórica dos direitos humanos. 3. ed. rev. e ampl. São Paulo: Saraiva, 2003.

COOLEY, Thomas M. Princípios gerais de direito constitucional nos Estados Unidos da América. Trad. e anot. Ricardo Rodrigues Gama. 1. ed. Campinas: Russell, 2002.

COSTA, Marcelo Freire Sampaio. Dano moral (extrapatrimonial) coletivo. São Paulo: LTr, 2009.

COUTO, Guadalupe Louro Turos. A efetividade da liquidação e da execução da tutela jurisdicional coletiva na área trabalhista e o Código Brasileiro de Processos Coletivos. In: GRINOVER, Ada Pellegrini; MENDES, Aluísio Gonçalves de Castro; WATANABE, Kazuo (Coords.). Direito processual coletivo e o anteprojeto de Código Brasileiro de Processos Coletivos. São Paulo: Revista dos Tribunais, 2007. 
CREMONEZE, Paulo Henrique. Dano moral: quantificação da indenização segundo a doutrina do punitive damage. Disponível em: <http://jus.com.br./artigos/18529/danomoral-quantificacao-da-indenizacao-segundo-a-doutrina-do-punitive-damage $>$ Acesso em: 02 set. 2013.

CRISE e o 'ativismo' dos TRTs. Estadão.com. 08 abr. 2009 Disponível em: $<$ http://www.estadao.com.br/noticias/impresso,a-crise-e-o-ativismo-dostrts,351642,0.htm>. Acesso em: 03 nov. 2013.

CRUZ E TUCCI, José Rogério. Garantias do processo sem dilações indevidas. In: CRUZ E TUCCI, José Rogério (Coord.). Garantias constitucionais do processo civil. São Paulo: Revista dos Tribunais, 1999. p. 234-262.

CY-PRÈS doctrine. The Free Dictionary. Disponível em <http://encyclopedia.thefreedictionary.com/cy+pres///>. Acesso em: 30 set. 2013.

DALAZEN, João Oreste. Aspectos do dano moral trabalhista. Revista LTr, São Paulo, v. 64, n. 1, p. 7-14, jan. 2000.

DALLARI, Dalmo de Abreu. O poder dos juízes. 3. ed. rev. São Paulo: Saraiva, 2010.

DANIEL, Juliana Maia. Discricionariedade administrativa em matéria de políticas públicas. In: GRINOVER, Ada Pellegrini; WATANABE, Kazuo (Coords.). O controle jurisdicional de políticas públicas. Rio de Janeiro: Forense, 2011. p. 93-124.

DANTAS, David Diniz. Interpretação constitucional no pós-positivismo: teoria e casos práticos. 2. ed. São Paulo: Madras, 2005.

DICIONÁRIO Larousse Cultural da Língua Portuguesa. São Paulo: Nova Cultural, 1999.

DIDIER JUNIOR, Fredie. Curso de direito processual civil: teoria geral do processo e processo de conhecimento. 10. ed. Salvador, Podivm, 2008. v. 1.

Pressupostos processuais e condições da ação. São Paulo: Saraiva, 2005.

; ZANETI JUNIOR, Hermes. Curso de direito processual civil: processo coletivo.

3. ed. rev., ampl. e atual. Salvador, Podivm, 2008. v. 4.

DINAMARCO, Candido Rangel. Instituições de direito processual civil. São Paulo: Malheiros, 2004. v. 1, p. 224-225. . A instrumentalidade do processo. São Paulo: Revista dos Tribunais, 1986. 
DINAMARCO, Cândido Rangel. O princípio do contraditório. Revista da Procuradoria Geral do Estado de São Paulo, São Paulo, n. 19, p. 21-38, dez. 1981/dez. 1982.

- A reforma do Código de Processo Civil. 4. ed. rev. ampl. e atual. São Paulo: Malheiros, 1997. p. 21-22.

DORETTO, Fernanda Orsi Baltrunas. Dano moral coletivo. 2008. Tese (Doutorado em Direito) - Faculdade de Direito, Universidade de São Paulo, 2008.

DÓRIA, Sampaio. Princípios constitucionaes. São Paulo: Saraiva, 1926. Grafia original.

DWORKIN, Ronald. Law's empire. Cambridge: Harvard University Press, 1986.

. Levando os direitos a sério. São Paulo: Martins Fontes, 2002.

Taking rights seriously. 2. ed. London: Gerald Duckworth, 1978.

. Uma questão de princípio. São Paulo: Martins Fontes, 2000.

ESPÍNDOLA, Ruy Samuel. Conceito de princípios constitucionais. 2. ed. rev., atual. e ampl. São Paulo: Revista dos Tribunais, 2002.

ESPÍNDOLA FILHO, Eduardo. Prefácio. In: BRASIL, Ávio. O dano moral no direito brasileiro. Rio de Janeiro: Livraria Jacinto, 1944.

ESSER, Josef. Princípio y norma em la elaboración jurisprudencial del derecho Privado. Trad. de Eduardo Valenti Fiol. Barcelona: Bosch, 1961.

FELICIANO, Guilherme Guimarães. Ativismo judicial para bom entendedor. Disponível em: <http://www1.folha.uol.com.br/fsp/opiniao/fz2505200909.htm>. Acesso em: 03 nov. 2013.

Os princípios do direito processual do trabalho e o anteprojeto de processo laboral da décima quinta região do trabalho. Revista do Instituto do Direito Brasileiro da Faculdade de Direito da Universidade de Lisboa - RIDB, ano 2, n. 7, p. 6853-6888, 2013. Disponível em: < http://www.idb-fdul.com />. Acesso em: 12 jun. 2013.

FERNANDES, Suellen. Juiz destina indenização trabalhista a entidades carentes do Vale do Paraíba. G1 - o Portal de Notícias da Globo. Disponível em: $<$ http://m.g1.globo.com/sp/vale-do-paraiba-regiao/noticia/2013/12/juiz-destinaindenizacao-de-acoes-entidades-carentes-do-vale-do-paraiba.html>. Acesso em: 04 dez. 2013. 
FERRAZ JR, Tércio Sampaio. O Judiciário frente à divisão dos poderes: um princípio em decadência. Revista USP, São Paulo, n. 21, p. 12-21, mar./maio, 1994.

FERREIRA, Cristiane Aneolito. Termo de ajuste de conduta celebrado perante o Ministério Público do Trabalho. 2011. Dissertação (Mestrado) - Faculdade de Direito, Universidade de São Paulo, São Paulo, 2011.

FILOMENO, José Geraldo Brito. Titulo II Das infrações penais, art. 61-80. In: GRINOVER, Ada Pellegrini et. al. Código Brasileiro de Defesa do Consumidor: comentado pelos autores do Anteprojeto. 8. ed. Rio de Janeiro: Forense Universitária, 2005 .

FISS, Owen. Um novo processo civil: estudos norte-americanos sobre jurisdição, constituição e sociedade. Coord. da Trad. Carlos Alberto de Salles. Trad. Daniel Porto Godinho da Silva, Melina de Medeiros Rós. São Paulo: Revista dos Tribunais, 2004.

FONSECA, Arnoldo Medeiros da. Dano moral. In: Santos, J. M. Carvalho (Coord.). Repertório de direito brasileiro. Rio de Janeiro: Borsoi, 1962. v. 14, p. 249-250.

FRANK, Theodore H. Class Action Watch - Cy Pres Settlements. Disponível em: <http://www.fed-soc.org/doclib/20080404_FrankCAW7.1.pdf>. Acesso em: 11 out. 2013.

FREIRE, Tatiane; BRAGA, Mariana. Presidentes aprovam seis metas nacionais para garantir mais eficiência ao Judiciário em 2014. Conselho Nacional de Justiça (CNJ), 19 nov. 2013. Disponível em: <http://www.cnj.jus.br/noticias/cnj/26931-presidentesaprovam-seis-metas-nacionais-para-garantir-mais-eficiencia-ao-judiciario-em-2014>.

Acesso em: 10 dez. 2013.

FUJITA, Jorge Shiguemitsu. Dano moral causado à pessoa jurídica no direito brasileiro. Cadernos de Direito, Piracicaba, v. 9, n. 16-17, p. 117-139, jan./dez. 2009.

GARCIA, Gustavo Filipe Barbosa. Meio ambiente do trabalho: direito, segurança e medicina do trabalho. São Paulo: Método, 2006.

GAVRONSKI, Alexandre Amaral. II - Das origens ao futuro da lei de ação civil pública: o desafio de garantir acesso à justiça com efetividade. In: MILARÉ, Édis (Coord.). A ação civil pública após 20 anos: efetividade e desafios. São Paulo: Revista dos Tribunais, 2005.

GERALDES, Antonio Santos Abrantes. Temas da reforma do processo civil. 2. ed. rev. e ampl. Coimbra: Almedina, 1998. v. 1. 
GIDI, Antonio. Las acciones colectivas em Estados Unidos. In: GIDI, Antonio; FERRER MC-GRECOR, Eduardo (Coords.). Processos colectivos: la tutela de los derechos colectivos e individuales en una perspectiva comparada. México-DF: Editorial Porrúa, 2003. p. 8-11.

. A class action como instrumento de tutela coletiva dos direitos: as ações coletivas em uma perspectiva comparada. São Paulo: Revista dos Tribunais, 2007.

Código de Processo Civil Coletivo: um modelo para países de direito escrito. Revista de Processo, São Paulo, v. 28, n. 111, p. 192-208, jul./set. 2003.

Coisa julgada e litispendência em ações coletivas: mandado de segurança coletivo, ação coletiva de consumo, ação coletiva ambiental, ação civil pública, ação popular. São Paulo: Saraiva, 1995.

Rumo a um Código de Processo Civil Coletivo: a codificação das ações coletivas no Brasil. Rio de Janeiro: Forense, 2008.

; FERRER MC-GRECOR, Eduardo (Coords.). Processos colectivos: la tutela de los derechos colectivos e individuales en una perspectiva comparada. México-DF: Editorial Porrúa, 2003.

; __ (Coords.). La tutela de los derechos difusos, colectivos e individuales homogéneos: hacia um Código Modelo para Iberoamérica. México: Porrúa, 2003.

GIDI, Antonio's Scholarly Papers. Disponível em: <http://ssrn.com/author=564684>.

GÓES, Gisele Santos Fernandes. O pedido de dano moral coletivo na ação civil pública do Ministério do Trabalho. In: MAZZEI, Rodrigo; NOLASCO, Rita Dias. Processo civil coletivo. São Paulo: Quartier Latin, 2005. p. 469-481.

GOMES, Orlando. Obrigações. 5. ed. Rio de Janeiro: Forense, 1978.

GRANDINETTI, Luiz Gustavo. Responsabilidade por dano não-patrimonial a interesse difuso (dano moral coletivo). Revista da Emerj, Rio de Janeiro, v. 3, n. 9, p. 24-31, 2000.

GRINOVER, Ada Pellegrini. O conteúdo da garantia do contraditório. In: GRINOVER, Ada Pellegrini. Novas tendências do direito processual de acordo com a Constituição de 1988. 2. ed. Rio de Janeiro: Forense Universitária, 1990.

O controle jurisdicional de políticas públicas. In: GRINOVER, Ada Pellegrini; WATANABE, Kazuo (Coords.). O controle jurisdicional de políticas públicas. Rio de Janeiro: Forense, 2011. 
GRINOVER, Ada Pellegrini. Direito processual coletivo. In: GRINOVER, Ada Pellegrini; MENDES, Aluísio Gonçalves de Castro; WATANABE, Kazuo (Coords.). Direito processual coletivo e o anteprojeto de Código Brasileiro de Processos Coletivos. São Paulo: Revista dos Tribunais, 2007.

A marcha do processo. Rio de Janeiro: Forense Universitária, 2000.

. A problemática dos interesses difusos. In: GRINOVER, Ada Pellegrini (Coord.). A tutela dos interesses difusos. São Paulo: Max Limonad, 1984.

O processo: estudos e pareceres. São Paulo: Perfil, 2005.

et. al. Código Brasileiro de Defesa do Consumidor: comentado pelos autores do Anteprojeto. 8. ed. Rio de Janeiro: Forense Universitária, 2005.

; MENDES, Aluísio Gonçalves de Castro; WATANABE, Watanabe (Coords.). Direito processual coletivo e o anteprojeto de Código Brasileiro de Processos Coletivos. São Paulo: Revista dos Tribunais, 2007.

GUERRA FILHO, Willis Santiago. Sobre o princípio da proporcionalidade. In: LEITE, George Salomão (Coord.). Dos princípios constitucionais: considerações em torno das normas principiológicas da Constituição. São Paulo: Malheiros, 2003.

. Teoria processual da Constituição. São Paulo: Celso Bastos Editor, 2000.

HART, Herbert L.A. O conceito de direito. 2. ed. Lisboa: Fundação Calouste Gulbenkian, 1996.

HECK, Luis Afonso. Regras, princípios jurídicos e sua estrutura no pensamento de Robert Alexy. In: LEITE, George Salomão (Coord.). Dos princípios constitucionais: considerações em torno das normas principiológicas da Constituição. São Paulo: Malheiros, 2003.

JACOB, César Augusto Alckmin. A reserva do possível: obrigação de previsão orçamentária e de aplicação da verba. In: GRINOVER, Ada Pellegrini; WATANABE, Kazuo (Coords.). O controle jurisdicional de políticas públicas. Rio de Janeiro: Forense, 2011. p. 237-283.

JAPIASSÚ, Hilton; MARCONDES, Danilo. Dicionário básico de filosofia. 3. ed. rev. e ampliada. Rio de Janeiro: Jorge Zahar, 1996. 
JUSTIÇA mantém condenação do Magazine Luiza ao pagamento de $\mathrm{R} \$$ 1,5 mi por dumping social. Disponível em: <http://mptprt15.jusbrasil.com.br/noticias/112071265/justica-mantem-condenacao-do-magazine-luizaao-pagamento-de-r-15-mi-por-dumping-social>. Acesso em: 09 dez. 2013.

KELSEN, Hans. Teoria pura do direito. 4. ed. São Paulo: Martins Fontes, 1994.

Teoria pura do direito: introdução à problemática científica do direito. Trad. de J. Cretella Jr., Agnes Cretella. 3. ed. rev. da trad. São Paulo: Revista dos Tribunais, 2003. Prólogo da edição de Viena. Prólogo de Kelsen à edição de Thévenaz.

KRELL, Andreas J. Direitos sociais e controle judicial no Brasil e na Alemanha: os (des)caminhos de um direito constitucional comparado. Porto Alegre: Sérgio Antonio Fabris, 2002.

LARENZ, Karl. Metodologia da ciência do direito. 3. ed. Tradução de José Lamego. Lisboa: Serviço de Educação Fundação Calouste Gulbenkian, 1997.

LEGAL Esoterica: The Cy Pres Doctrine. Disponível em: $<$ http://hennepin.membershipsoftware.org/article_content.asp?article=1647>. Acesso em: 30 set. 2013.

LEITE, Carlos Henrique Bezerra. Curso de direito processual do trabalho. 2. ed. São Paulo: LTr, 2004.

- Direito e processo do trabalho: na perspectiva dos direitos humanos. Rio de Janeiro: Revovar, 2003.

- Ministério Público do Trabalho: doutrina, jurisprudência e prática: ação civil pública, ação anulatória, inquérito civil. 3. ed. São Paulo: LTr, 2006.

LEONEL, Ricardo de Barros. A causa petendi nas ações coletivas. In: CRUZ E TUCCI, José Rogério; BEDAQUE, José Roberto dos Santos. Causa de pedir e pedido no processo civil (questões polêmicas). São Paulo: Revista dos Tribunais, 2002.

LOPEZ, Teresa Ancona. O dano estético: responsabilidade civil. 2. ed. rev.atual.e ampl. São Paulo: Revista dos Tribunais, 1999.

LUCON, Paulo Henrique dos Santos. Garantia do tratamento paritário das partes. In: TUCCI, José Rogério Cruz e (Coord.). Garantias constitucionais do processo civil. 1. ed. São Paulo: Revista dos Tribunais, 1999. 
LUCON, Paulo Henrique dos Santos; GABBAY, Daniela Monteiro. Superação do modelo processual rígido pelo Anteprojeto do Código Brasileiro de Processos Coletivos, à luz da atividade gerencial do juiz. In: GRINOVER, Ada Pellegrini; MENDES, Aluísio Gonçalves de Castro; WATANABE, Kazuo (Coords.). Direito processual coletivo e o anteprojeto de Código Brasileiro de Processos Coletivos. São Paulo: Revista dos Tribunais, 2007. p.78-89.

MACEDO JÚNIOR, Ronaldo Porto. Ação civil pública, o direito social e os princípios. In: YARSHELL, Flávio Luiz; MORAES, Maurício Zanoide de (Orgs.). Estudos em homenagem à professora Ada Pellegrini Grinover. São Paulo: DPJ, 2005.

Ação civil pública: Lei n. 7.347/85 - 15 anos.2. ed. São Paulo: Revista dos Tribunais, 2002.

MACHADO, Antonio Cláudio da Costa. A intervenção do Ministério Público no processo civil brasileiro. 2. ed. rev. e atual. São Paulo: Saraiva, 1998.

MAGAZINE Luiza condenado por dumping social. Disponível em: <http://jcrs.uol.com.br/site/noticia.php?codn=100106>. Acesso em: 09 dez. 2013.

MAGAZINE Luiza sofre condenação de R \$ 1,5 mi por dumping social” Disponível em: <http://www.jornalcidadesonline.com/noticias1067.html>. Acesso em: 09 dez. 2013.

MALlET, Estêvão. O novo Código Civil e o Direito do Trabalho. Revista do TRT da $15^{a}$ Região, Campinas, n. 22, p. 55-70, jun. 2003.

MANCUSO, Rodolfo de Camargo. Interesses difusos: conceito e legitimação para agir. 5. ed. rev. e atual. São Paulo: Revista dos Tribunais, 2000.

A projetada participação equânime dos co-legitimados à propositura da ação civil pública: da previsão normativa à realidade forense. In: LUCON, Paulo Henrique dos Santos (Coord.). Tutela coletiva: 20 anos da Lei de Ação Civil Pública e do Fundo de Defesa de Direitos Difusos, 15 anos do Código de Defesa do Consumidor. São Paulo: Atlas, 2006.

MARANHÃO, Clayton. O controle jurisdicional de políticas públicas. In: GOZZOLI, Maria Clara et al. (Coords.). Em defesa de um novo sistema de processos coletivos: estudos em homenagem a Ada Pellegrini Grinover. São Paulo: Saraiva, 2010.

MARINONI, Luiz Guilherme. Técnica processual e tutela de direitos. São Paulo: Revista dos Tribunais, 2004. 
MARINONI, Luiz Guilherme. Técnica processual e tutela de direitos. 3. ed. rev. atual. São Paulo: Revista dos Tribunais, 2010.

. Teoria geral do processo. 2. ed. rev.e atual. São Paulo: Revista dos Tribunais, 2007. (Curso de Processo Civil, v. 1).

MARQUES, José Frederico. Ensaio sobre a jurisdição voluntária. 2. ed. São Paulo: Saraiva, 1959.

Instituições de direito processual civil. 3. ed. Rio de Janeiro, 1966. v. 3.

MARTINEZ, Luciano. O dano moral social no âmbito trabalhista. In: MALLET, Estevão; SANTOS, Enoque Ribeiro dos (Coords.). Tutela processual coletiva trabalhista: temas. São Paulo: LTr, 2010.

MARTINS, Sérgio Pinto. Comentários à CLT. 7. ed. São Paulo: Atlas, 2003.

Dano moral decorrente do contrato de trabalho. 3. ed. São Paulo: Atlas, 2012.

Direito processual do trabalho: doutrina e prática forense; modelos de petições, recursos, sentenças e outros. 21. ed. São Paulo: Atlas, 2004.

MAZZILLI, Hugo Nigro. A defesa dos interesses difusos em juízo. 9. ed. rev. e atual. São Paulo: Saraiva, 1997.

. A defesa dos direitos difusos em juízo. 20. ed. São Paulo: Saraiva, 2007.

MEDAUAR, Odete. Direito administrativo moderno. São Paulo: Revista dos Tribunais, 2000 .

MEDEIROS NETO, Xisto Tiago de. Dano moral coletivo. 3. ed. rev.atual. e ampl. São Paulo: LTr, 2012.

MEDINA, José Miguel Garcia. Sobre os poderes do juiz na atuação executiva dos direitos coletivos - considerações e perspectivas, à luz do Anteprojeto de Código Brasileiro de Processos Coletivos. In: GRINOVER, Ada Pellegrini; MENDES, Aluísio Gonçalves de Castro; WATANABE, Kazuo (Coords.). Direito processual coletivo e o anteprojeto de Código Brasileiro de Processos Coletivos. São Paulo: Revista dos Tribunais, 2007.

MEIRELLES, Hely Lopes. Direito administrativo brasileiro. São Paulo: Malheiros, 1989.

MELO, Raimundo Simão de. Ação civil pública na Justiça do Trabalho. 2. ed. São Paulo: LTr, 2004. 
MELO, Raimundo Simão de. Direito ambiental do trabalho e a saúde do trabalhador. 3. ed. São Paulo: LTr, 2008.

Direito ambiental do trabalho e a saúde do trabalhador: responsabilidades legais, dano material, dano moral, dano estético, indenização pela perda de uma chance, prescrição. São Paulo: LTr, 2004.

MENDES, Aluísio Gonçalves de Castro. O Anteprojeto de Código Brasileiro de Processos Coletivos: visão geral e pontos sensíveis. In: GRINOVER, Ada Pellegrini; MENDES, Aluísio Gonçalves de Castro; WATANABE, Kazuo (Coords.). Direito processual coletivo e o anteprojeto de Código Brasileiro de Processos Coletivos. São Paulo: Revista dos Tribunais, 2007.

MENEZES, Carlos Alberto; CAVALIERI FILHO, Sérgio. Comentários ao novo Código Civil. 2. ed. Rio de Janeiro: Forense, 2007. v. 13.

MILLER, Geoffey P.; SINGER, Lori. Nonpecuniary class action settlements. New York University, Center for Law and Business, Working Paper, n. 98-013, Feb. 1998. Disponível em: <http://ssrn.com/abstract=169526>.

MIRANDA, Vicente. Poderes do Juiz no processo civil brasileiro. São Paulo: Saraiva, 1993.

MIRRA, Alvaro Luiz Valery. A ação civil pública e a reparação do dano ao meio ambiente. São Paulo: Juarez de Oliveira, 2002.

MONTESQUIEU. Do espírito das leis. 1. ed. São Paulo, Abril, 1973(Coleção Os Pensadores, v. 21).

MONTESSO, Cláudio José; STERN, Maria de Fátima Coelho Borges; ELY, Leonardo (Coords.). $1^{a}$. Jornada de Direito Material e Processual na Justiça do Trabalho. São Paulo: LTr, 2008.

MORAES, Maria Celina Bodin de. Danos à pessoa humana: uma leitura civilconstitucional dos danos morais. Rio de Janeiro: Renovar, 2003.

NASCIMENTO JÚNIOR, Adil Guedes do. Dano moral no direito do trabalho: a majoração do quantum indenizatório à luz do punitive damage. Revista Eletrônica, Rio de Janeiro, n. 2, p. 1-42, out./dez. 2011. Disponível em: <http://www.trt1.jus.br/c/document_library/get_file?uuid=c7cfd7c5-daac-4302-826fe8d28d679c70\&groupId=10157>. 
NERY JUNIOR, Nelson. Codificação ou não do processo coletivo? De Jure: revista jurídica do Ministério Público do Estado de Minas Gerais, Belo Horizonte, v. 7, p. 154$155,2006$.

Princípios do Processo Civil na Constituição Federal. 8. ed. rev., ampl. e atual.com as novas Sumulas do STF e com análise sobre a relativização da coisa julgada. São Paulo: Revista dos Tribunais, 2004. (Coleção Estudos de Direito de Processo Enrico Tullio Liebman, v. 21).

NOLASCO, Rita Dias. Contornos nucleares da execução coletiva. In: MAZZEI, Rodrigo; NOLASCO, Rita Dias. Processo civil coletivo. São Paulo: Quartier Latin, 2005. p. 430-456.

OLIVEIRA, Carlos Alberto Álvaro de. O formalismo-valorativo no confronto com o formalismo excessivo. Revista de Processo, São Paulo, n. 137, p. 7-31, ago. 2006.

Garantia do contraditório. In: CRUZ E TUCCI, José Rogério (Coord.). As garantias constitucionais do processo civil: homenagem aos 10 anos da Constituição Federal de 1988. 1. ed., 2.tir. São Paulo: Revista dos Tribunais, 1999.

Poderes do juiz e visão cooperativa do processo. Revista da Ajuris, Associação dos Juízes do Rio Grande do Sul, Porto Alegre, ano 30, n. 90, p. 55-84, jun. 2003.

OLIVEIRA, Paulo Eduardo Vieira de. O dano pessoal no direito do trabalho. São Paulo: LTr, 2002.

OLIVEIRA, Sebastião Geraldo de. Indenizações por acidente do trabalho ou doença ocupacional. 6. ed. rev. ampl.e atual. São Paulo: LTr, 2011.

OLIVEIRA, Swarai Cervone de. Poderes do juiz nas ações coletivas. São Paulo: Atlas, 2009. (Coleção Atlas de Processo Civil. Coord. Carlos Alberto Carmona).

Poderes do juiz nos processos coletivos. In: GOZZOLI, Maria Clara et al. (Coords..). Em defesa de um novo sistema de processos coletivos: estudos em homenagem a Ada Pellegini Grinover. São Paulo: Saraiva, 2010.

OLIVEIRA JÚNIOR, Waldemar Mariz. Tutela jurisdicional dos interesses coletivos. In: GRINOVER, Ada Pellegrini (Coord.). A tutela dos interesses difusos. São Paulo: Max Limonad, 1984.

PEREIRA, Caio Mário da Silva. Responsabilidade civil. 8. ed. Rio de Janeiro: Forense, 1996. 
PEREIRA, Marco Antonio Marcondes. Dano moral contra a coletividade: ocorrências na ordem urbanística. Disponível em: <www.mp.sp.gov.br.> Acesso em: 20 ago. 2013.

PEREIRA, Rui Soares. A responsabilidade por danos não patrimoniais: do incumprimento das obrigações do Direito Civil Português. Coimbra: Coimbra Editora, 2009.

PERELMAN, Chaim; OLBRECHTS-TYTECA, Lucie. Tratado de la argumentación: la nueva retórica. Trad. Julia S. Munoz. Madri: Gredos, 1989.

PINHO, Humberto Dalla Bernardina de. A natureza jurídica do direito individual homogêneo e sua tutela pelo Ministério Público como forma de acesso à justiça. Rio de Janeiro: Forense, 2002.

PIOVESAN, Flávia. Proteção Internacional dos direitos econômicos, sociais e culturais. In: SARLET, Ingo Wolfgang (Org.). Direitos fundamentais sociais: estudos de direito constitucional, internacional e comparado. Rio de Janeiro: Renovar, 2003.

PISCO, Cláudia de Abreu Lima. O Anteprojeto do Código Brasileiro de Processos Coletivos, os Dissídios coletivos e outras ações coletivas trabalhistas. In: GRINOVER, Ada Pellegrini; MENDES, Aluísio Gonçalves de Castro; WATANABE, Kazuo. (Coords.). Direito processual coletivo e o anteprojeto de Código Brasileiro de Processos Coletivos. São Paulo: Revista dos Tribunais, 2007.

PRADO, Erlan José Peixoto do. A ação civil pública e sua eficácia no combate ao trabalho em condições análogas à de escravo: o dano moral coletivo. In: VELLOSO, Gabriel; FAVA, Marcos Neves (Coords.). Trabalho escravo contemporâneo: o desafio de superar a negação. São Paulo: LTr, 2006.

PRADO, Lídia Reis de Almeida. O juiz e a emoção: aspectos da lógica da decisão judicial. 2. ed. Campinas (SP): Millennium, 2003.

PROJETO das ações coletivas no RS disputará Prêmio Innovare. Conselho Nacional de Justiça (CNJ). Disponível em: <http://www.cnj.jus.br/component/content/article/96noticias/4922-projeto-das-as-coletivas-no-rs-disputarro-innovare $>$. Acesso em: 05 nov. 2013.

RAMOS, André de Carvalho. Ação civil pública e o dano moral coletivo. Revista de Direito do Consumidor, São Paulo, n. 25, p. 80-90, jan./mar. 1998.

RAMOS, Elival da Silva. Ativismo judicial: parâmetros dogmáticos. São Paulo: Saraiva, 2010. 
RAPASSI, Rinaldo. Indenização por dano coletivo deve ser paga à sociedade. Disponível em: <http://www.anamatra.org.br/index.php/artigos/indenizacao-por-dano-coletivo-deveser-paga-a-sociedade>. Acesso em: $10 \mathrm{dez} .2013$.

REALE, Miguel. Filosofia do direito. 20. ed. São Paulo: Saraiva, 2002.

REIS, Clayton. Avaliação do dano moral. Rio de Janeiro: Forense, 1998.

Dano moral. 4. ed. Rio de Janeiro: Forense, 1995.

. Os novos rumos da indenização do dano moral. Rio de Janeiro: Forense, 2002.

REVISTA LTr, São Paulo, v. 71, n. 9, p. 1142-1148, set. 2000.

RIBEIRO, Saulo Telles. Das questões relevantes sobre o dano moral coletivo. Artigo Científico. Escola de Magistratura do Estado do Rio de Janeiro, 2012. Disponível em: $<$ http://www.emerj.tjrj.jus.br/paginas/rcursodeespecializacao_latosensu/edicoes/n1novemb ro2012/pdf/SauloTellesRibeiro.pdf>. Acesso em: 28 ago. 2013.

RIGAUX, François. A lei dos juízes. Trad. Edmir Missio; rev. da trad. Maria Ermantina Galvão; rev.téc. Gildo Leitão Rios. São Paulo: Martins Fontes, 2000.

RODRIGUES, Marcelo Abelha. Elementos de direito processual civil. 2. ed. rev. atual.e ampl. São Paulo: Revista dos Tribunais, 2000. v. 1.

Ponderações sobre a fluid recovery do artigo 100 do CDC. In: MAZZEI, Rodrigo; NOLASCO, Rita Dias. Processo civil coletivo. São Paulo: Quartier Latin, 2005. p. 459-468.

RODRIGUES, Silvio. Direito civil. 20. ed. rev. e atual. São Paulo: Saraiva, 2003. v. 4.

ROSAS, Roberto. Direito processual constitucional: princípios constitucionais do processo civil. 3. ed. rev.atual. e ampl. São Paulo: Revista dos Tribunais, 1997.

ROSS, Alf. Direito e justiça. Trad. Edson Bini, rev. téc. Alysson Leandro Mascaro. 1. reimpr. Bauru (SP): EDIPRO, 2003.

ROUSSEAU, Jean-Jacques. Do contrato Social: ensaio sobre a origem das línguas; Discurso sobre a origem e os fundamentos da desigualdade entre os homens. Trad. de Lourdes Santos Machado; intr. e notas de Paul Arbousse-Bastide e Lourival Gomes Machado. 5. ed. São Paulo: Nova Cultural, 1991. (Coleção Os pensadores, v. 6). 
SAAD, Eduardo Gabriel. Consolidação das Leis do Trabalho: comentada. 42. ed. atual.,rev. e ampl. São Paulo: LTr, 2009.

SADECK, Maria Tereza. Judiciário e arena pública: um olhar a partir da ciência política. In: GRINOVER, Ada Pellegrini; WATANABE, Kazuo (Coords.). O controle jurisdicional de políticas públicas. Rio de Janeiro: Forense, 2011. p. 1-32.

SALAZAR, Alcino de Paula. Reparação do dano moral. Rio de Janeiro: Encadernadora Kristina, 1943.

SALLES, Carlos Alberto de. Execução judicial em matéria ambiental. São Paulo: Revista dos Tribunais, 1998.

SANTOS, Enoque Ribeiro dos. Do microssistema processual de tutela coletiva ao fenômeno da parceirização jurisdicional trabalhista. 2010. Tese (Livre docência) Faculdade de Direito, Universidade de São Paulo. São Paulo, 2010.

A natureza objetiva do dano moral coletivo no direito do trabalho. Revista da Associação dos Magistrados da Justiça do Trabalho da $15^{a}$ Região - Amatra XV, Campinas, n. 5, 2012.

SANTOS, Ronaldo Lima. A equivocidade da competência territorial para as ações coletivas no Projeto de Lei no 5.139/2009. In: CORDEIRO, Juliana Vignoli (Org.). Ações coletivas: crítica para construção da nova Lei de Ação Civil Pública. Brasília: Ministério Público do Trabalho, 2011. p. 210-245.

SANTOS, Vivian Machado dos. Por dentro do FAT. Revista do BNDES, Rio de Janeiro, v. 13, n. 25, p. 3-14, dez. 2005. Disponível em: <http://www.bndes.gov.br/SiteBNDES/export/sites/default/bndes_pt/Galerias/Arquivos/co nhecimento/revista/rev2601.pdf>. Acesso em: 19 set. 2013.

SCHIAVI, Mauro. Ações de reparação por danos morais decorrentes da relação de trabalho. 4. ed. rev. e ampliada. São Paulo: LTr, 2011.

SIGNIFICADO de Dumping. Disponível em: <http://www.significados.com.br/dumping/>. Acesso em: 09 dez. 2013.

SILVA, Américo Luís Martins da. O dano moral e a sua reparação civil. São Paulo: Revista dos Tribunais, 1999. 
SILVA, Érica Barbosa. Os direitos individuais homogêneos e a Lei $\mathrm{n}^{\circ} 11.232 / 2005$. In: SALLES, Carlos Alberto de (Coord.). As grandes transformações do processo civil brasileiro: homenagem ao Professor Kazuo Watanabe. São Paulo: Quartier Latin do Brasil, 2009.

SILVA, José Afonso da. Aplicabilidade das normas constitucionais. 3.ed.São Paulo: Malheiros, 1998.

2006.

Curso de direito constitucional positivo. 27. ed. rev.e atual. São Paulo: Malheiros,

SILVA, Ricardo Gariba. O dano moral e sua liquidação. Artigo científico. Disponível em: <http://www.forp.usp.br/restauradora/etica/dm.html>. Acesso em: 27 ago. 2013.

SILVA, Suzana Costa; MANDALOZZO, Silvana Souza Netto. Dano moral coletivo decorrente da prática de dumping social. Revista LTr, São Paulo, v. 74, n. 8, p. 955-964, ago. 2010.

SOUTO MAIOR, Jorge Luiz. O dano social e sua reparação. Revista LTr, São Paulo, v. 71, n. 11, p. 1317-1323, nov. 2007.

SOUZA, Rodrigo Trindade de. Punitive damages e o direito do trabalho brasileiro: adequação das condenações punitivas para a necessária repressão da delinquência patronal. Revista LTr, São Paulo, v. 75, n. 5, p. 565-587, maio 2011.

STUMM, Raquel Denize. Princípio da proporcionalidade no direito constitucional brasileiro. São Paulo: Livraria do Advogado, 1995.

SZANIAWSKI, Elimar. Apontamentos sobre o princípio da proporcionalidade-igualdade. Revista Trimestral de Direito Civil, Rio de Janeiro, v. 5, 2000.

TÁCITO, Caio. A razoabilidade das leis. Revista de Direito Administrativo, Rio de Janeiro, n. 204, p. 1-7, abr./jun. 1996.

TARGA, Maria Inês Corrêa de Cerqueira. Contaminação do Bairro Recanto dos Pássaros em Paulínia (SP): caso SHELL/BASF. Revista da Associação dos Magistrados da Justiça do Trabalho da 15ª Região, Amatra XV, Campinas, ano 4, p. 252-303, 2011.

TARUFFO, Michele. Il significado costituzionale dell'obligo di motivazione. In: GRINOVER, Ada Pelegrini; DINAMARCO, Cândido Rangel; WATANABE, Kazuo (Coords..). Participação e processo. São Paulo: Revista dos Tribunais, 1988. 
TARZIA, Giuseppe. O novo processo civil de cognição na Itália. Revista de Processo, São Paulo, v. 20, n. 79, p. 51-64, jul./set. 1995.

TAVARES, André Ramos. Elementos para uma teoria geral dos princípios na perspectiva constitucional. In: LEITE, George Salomão (Coord.). Dos princípios constitucionais: considerações em torno das normas principiológicas da Constituição. São Paulo: Malheiros, 2003.

TEIXEIRA, João Carlos. Dano moral coletivo na relação de emprego. In: NORRIS, Roberto (Org.) Temas polêmicos de direito e processo do trabalho. São Paulo: LTr, 2000.

TEIXEIRA JÚNIOR, José Guido. Quantificação dos danos morais e materiais: e o acidente do trabalho no setor sucroalcooleiro. São Paulo: LTr, 2011.

THEODORO JÚNIOR, Humberto. Direito e processo: direito processual civil ao vivo. Rio de Janeiro: Aide, 1995. v. 5.

TRAMONTE, Marina da Silva. A inadequação da destinação de recursos obtidos pelo MPT ao Fundo de Amparo ao Trabalhador e sua utilização em ações de política pública social. Revista de Direito Público, Londrina, v. 7, n. 1, p.149-164, jan./abr. 2012. Disponível em: $<$ http://www.uel.br/revistas/uel/index.php/direitopub/article/view/10369/10430>. Acesso em: 26 set. 2013.

TUCCI, Rogério Lauria. Constituição de 1988 e processo: regramentos e garantias constitucionais do processo. São Paulo: Saraiva, 1989.

VENTURI, Elton. Apontamentos sobre o processo coletivo, o acesso à justiça e o devido processo social. Revista da Procuradoria Geral do Estado do Paraná, Curitiba, v. 9, n. 4, p. 24-56, jul. 1987.

VENTURI, Elton. Aspectos Gerais do Projeto de Lei do Sistema Único de Ações Coletivas: objeto material e princípio. In: CORDEIRO, Juliana Vignoli (Org.). Ações coletivas: crítica para construção da nova Lei de Ação Civil Pública. Brasília: Ministério Público do Trabalho, 2011.

Responsabilidade civil por danos causados aos direitos difusos e coletivos. Revista de Direito do Consumidor, São Paulo, n. 15, p. 79-98, jul./set. 1995. 
VENTURI, Elton. A tutela executiva dos direitos difusos nas ações coletivas. In: WAMBIER, Teresa Arruda Alvim (Coord.). Processo de execução e assuntos afins. Coord. Teresa Arruda Alvim Wambier. São Paulo: Editora Revista dos Tribunais, 1998. (Col. Araken de Assis et al.).

VIANNA, Luiz Werneck et al. A judicialização da política e das relações sociais no Brasil. Rio de Janeiro: Revan, 1999.

VIGORITI, Vincenzo. Interessi collettivi e processo: la legittimazione ad agire. Milano: Dott. A. Giuffrè, 1979.

WAMBIER, Luiz Rodrigues; WAMBIER, Teresa Arruda Alvim. A prova do dano moral da pessoa jurídica. In: YARSHELL, Flávio Luiz; MORAES, Maurício Zanoide de (Orgs.). Estudos em homenagem à professora Ada Pellegrini Grinover. São Paulo: DPJ, 2005. p. 800-806.

WATANABE, Kazuo. Acesso à justiça e sociedade moderna. In: GRINOVER, Ada Pelegrini; DINAMARCO, Cândido Rangel; WATANABE, Kazuo (Coords..). Participação e processo. São Paulo: Revista dos Tribunais, 1988.

\section{DOCUMENTOS CONSULTADOS}

ANTEPROJETO de Código Brasileiro de Processos Coletivos. Jan. 2007. Ministério da Justiça - Última versão. Incorporando Sugestões da Casa Civil, Secretaria de Assuntos Legislativos, PGFN e dos Ministérios Públicos de Minas Gerais, Paraná, Rio Grande do Sul e São Paulo. In: GRINOVER, Ada Pellegrini; MENDES, Aluísio Gonçalves de Castro; WATANABE, Kazuo (Coords.). Direito processual coletivo e o anteprojeto de Código Brasileiro de Processos Coletivos. São Paulo: Revista dos Tribunais, 2007. Anexo, 453-464.

ASSEMBLEIA LEGISLATIVA DO ESTADO DE SÃO PAULO - ALESP. Disponível em: <http://www.al.sp. gov.br/propositura/?id=99264>. Acesso em: 30 set. 2013.

BANCO NACIONAL DO DESENVOLVIMENTO - BNDES. Disponível em: $<$ http://www.bndes.gov.br/SiteBNDES/export/sites/default/bndes_pt/Galerias/Arquivos/em presa/fundos/FAT_Transf.pdf>. Acesso em: 19 set. 2013. 
CÂMARA DOS DEPUTADOS. COMISSÃO DE CONSTITUIÇÃO E JUSTIÇA E DE CIDADANIA. Projeto de Lei ${ }^{\circ}$ 5.139, de 2009. (Do Poder Executivo). Disponível em: $<$ http://www.camara.gov.br/proposicoesWeb/prop_mostrarintegra;jsessionid=FB874A820726 7A0DF1070D68FDE00FBB.node1 ? codteor=754582\&filename=Tramitacao-PL+5139/2009>. Acesso em: 10 dez. 2013.

. Disponível em: <http://www.camara.gov.br>. Acesso em: 03 set. 2013.

. $\quad P L \quad 5139 / 2009$. Disponível em: $<$ http://www.camara.gov.br/proposicoesWeb/fichadetramitacao?idProposicao=432485>. Acesso em: 20 nov. 2013.

- Projeto de Lei $n^{o}$ 5.139/2009. Disponível em: <http://www.camara.gov.br/sileg/integras/651669.pdf>. Acesso em: 12 jun. 2013.

CODICE Procedura Civile. Testolegge. Disponível em: <http://www.testolegge.com/italia/procedura-civile>. Acesso em: 28 out. 2013.

CÓDIGO de Processo Civil Coletivo - um modelo para Países de Direito Escrito (Anteprojeto original). In: GIDI, Antonio. Rumo a um Código de Processo Civil Coletivo: a codificação das ações coletivas no Brasil. Rio de Janeiro: Forense, 2008. Apêndice, p. 445-459.

CÓDIGO de Processo Civil Português. Scribd. Disponível em: <http://pt.scribd.com/doc/42939898/CODIGO-DE-PROCESSO-CIVIL-PORTUGUES>. Acesso em: 01 out. 2013.

CÓDIGO de Processo do Trabalho. Compilações legislativas Verbo Jurídico. Disponível em: <http://www.verbojuridico.com/download/codigoprocessotrabalho.pdf>. Acesso em: 01 out. 2013.

CÓDIGO Modelo de Processos Coletivos para Ibero-América. In: GRINOVER, Ada Pellegrini; MENDES, Aluísio Gonçalves de Castro; WATANABE, Kazuo (Coords.). Direito processual coletivo e o anteprojeto de Código Brasileiro de Processos Coletivos. São Paulo: Revista dos Tribunais, 2007. Anexo, p. 421-432.

CONGRESSO NACIONAL DOS MAGISTRADOS DA JUSTIÇA DO TRABALHO -
$\mathrm{XV}$ CONAMAT. Teses aprovadas. Disponível em: $<$ http://anamatra.tempsite.ws/conamat/teses_aprovadas.aspx>. Acesso em: 09 set. 2013. 
CONSELHO NACIONAL DE JUSTIÇA (CNJ). Resolução $n^{\circ} 125$, de 29 de novembro de 2010. Disponível em: <http://www.cnj.jus.br///images/atos_normativos/resolucao/resolucao_125_29112010_111 12013145136.pdf>. Acesso em: 04 nov. 2013.

CONSELHO SUPERIOR DA JUSTIÇA DO TRABALHO. 20/09/2013 - Chegou ao fim o II Seminário... Disponível em: $<$ http://www.csjt.jus.br/c/journal/view_article_content?groupId=955023\&articleId=209394 $8 \&$ version=1.0. $>$. Acesso em: 30 set. 2013.

TRT-GO.

Disponível em: $<$ http://www.csjt.jus.br/c/journal/view_article_content?groupId=990681\&articleId=107235 $8 \&$ version=1.0 $>$. Acesso em: 10 out. 2013.

TRT-PB.

Disponível

em:

$<$ http://www.csjt.jus.br/c/journal/view_article_content?groupId=990681\&articleId=113222 $8 \&$ version=1.0>. Acesso em: 10 out. 2013.

EXPOSIÇÃO de Motivos. Anteprojeto de Código Brasileiro de Processos Coletivos. Ada Pellegrini Grinover. In: GRINOVER, Ada Pellegrini; MENDES, Aluísio Gonçalves de Castro; WATANABE, Watanabe (Coords.). Direito processual coletivo e o anteprojeto de Código Brasileiro de Processos Coletivos. São Paulo: Revista dos Tribunais, 2007.

EXPOSIÇÃO de Motivos. Modelo de Processos Coletivos para Ibero-América. Out. 2004. Roberto Berizoce (Presidente) - Argentina; Ada Pellegrini Grinover - Brasil; Angel Landoni Sosa- Uruguai. In: GRINOVER, Ada Pellegrini; MENDES, Aluísio Gonçalves de Castro; WATANABE, Watanabe (Coords.). Direito processual coletivo e o anteprojeto de Código Brasileiro de Processos Coletivos. São Paulo: Revista dos Tribunais, 2007.

GOVERNO DE PORTUGAL. Código de Processo Civil. Disponível em <http://www.portugal.gov.pt/media/463728/c_digo_de_processo_civil_-_propostas.pdf>. Acesso em: 05 ago. 2013.

METAS Nacionais. Conselho Nacional de Justiça (CNJ). Disponível em: <http://www.cnj.jus.br/gestao-e-planejamento/metas>. Acesso em: 28 ago. 2013; 05 nov. 2013.

NOTA Técnica $\mathrm{n}^{\circ}$ 2/2007. Conselho Nacional de Justiça (CNJ). Disponível em: $<$ http://www.cnj.jus.br/atos-administrativos/atos-da-presidencia/317-notas-tecnicas/11209nota-tica-no-2-media>. Acesso em: 04 nov. 2013. 
NOVO Código de Processo Civil. Projeto de Lei $\mathrm{n}^{\circ}$ 8.046/2010. Disponível em: $<$ http://www.camara.gov.br/proposicoesWeb/prop_mostrarintegra?codteor=831805\&filena me=Tramitacao-PL+8046/2010>. Acesso em: 19 ago. 2013.

ORGANIZAÇÃO INTERNACIONAL DO TRABALHO (OIT). Constituição da Organização Internacional do Trabalho (OIT) e seu Anexo (Declaração de Filadélfia). Disponível em: <http://www.oit.org.br/sites/default/files/topic/decent_work/doc/constituicao_oit_538.pdf>. Acesso em: 04 nov. 2013.

PRESIDÊNCIA DA REPÚBLICA. II Pacto Republicano de Estado por um Sistema de Justiça mais Acessível, Ágil e Efetivo. Disponível em: <http://www.planalto.gov.br/ccivil_03/Outros/IIpacto.htm>. Acesso em: 10 out. 2013.

- Lei $n^{o}$ 7.998, de 11 de janeiro de 1990. Disponível em: <http://www.planalto.gov.br/ccivil_03/Leis/L7998.htm>. Acesso em: 24 set. 2013.

SENADO FEDERAL. Em 2004, Planalto, Congresso e STF lançaram o $1^{o}$ Pacto. $<$ http://www12.senado.gov.br/noticias/materias/2009/04/17/em-2004-planalto-congressoe-stf-lancaram-o-1o-pacto>. Acesso em: 10 out. 2013.

SUPERIOR TRIBUNAL DE JUSTIÇA. Disponível em: <www.stj.jus.br>. Acesso em: 23 ago. 2013.

SUPREME COURT OF CALIFORNIA RESOURCES. State of California v. Levi Strauss \& Co. (1986) 41 Cal.3d 460, 224 Cal.Rptr. 605; 715 P.2d 564. Stanford Law Review. Disponível em: <http://scocal.stanford.edu/opinion/state-california-v-levi-strauss-co30734>. Acesso em: 30 set. 2013.

SUPREMO TRIBUNAL FEDERAL. Disponível em: <http://www.stf.jus.br/portal/principal/principal.asp>. Acesso em: 25 nov. 2013.

Disponível em: <www.stf.jus.br>. Acesso em: 04 set. 2012.

TED Frank, Moody v Sears: Lawyers, \$1M. Class, \$2,402. Overlawyered weblog. May 5, 2007.

Disponível em: $<$ http://www.overlawyered.com/2007/05/moody_v_sears_lawyers_1m_class.html>. Acesso em: 11 out. 2013.

TRIBUNAL REGIONAL DO TRABALHO DA $2^{\mathrm{a}}$ REGIÃO. Andamento processual. Disponível em: <http://www.trt2.jus.br/cons-anda-2inst>. Acesso em: 16 out. 2013. 
TRIBUNAL REGIONAL DO TRABALHO DA 5 $5^{\mathrm{a}}$ REGIÃO. 2 $2^{\mathrm{a}}$. Turma. Recurso Ordinário $\quad \mathrm{n}^{\mathrm{o}} \quad$ 0000452-71.2011.5.05.0030RecOrd. Disponível em: $<$ http://www.trt5.jus.br/jurisprudencia/modelo/AcordaoConsultaBlobTexto.asp?v_id=3156 $50 \&$ texto $=$ FAT $>$.

TRIBUNAL REGIONAL DO TRABALHO DA $6^{\mathrm{a}}$ REGIÃO. Disponível em: <www.trt6.jus.br>. Acesso em: 13 set. 2013.

TRIBUNAL REGIONAL DO TRABALHO DA $8^{\mathrm{a}}$ REGIÃO. Disponível em: <www.trt8.jus.br>. Acesso em: 01 jul. 2012; 02 set. 2013.

TRIBUNAL REGIONAL DO TRABALHO DA $10^{\mathrm{a}}$ REGIÃO. Disponível em: $<$ http://www.trt10.jus.br>. Acesso em: 01 set. 2013.

TRIBUNAL REGIONAL DO TRABALHO DA 15 REGIÃO. Disponível em: <www.trt15.jus.br>. Acesso em: 20 fev. 2012; 31 mar. 2013; 20 set. 2013; 09 dez. 2013.

TRIBUNAL REGIONAL DO TRABALHO DA 20 REGIÃO. Disponível em: <www.trt20.jus.br>. Acesso em: 02 out. 2013.

TRIBUNAL SUPERIOR DO TRABALHO. Audiência Pública. Disponível em: <http://www.tst.jus.br/ASCS/audiencia_publica/index3.html>. Acesso em: 20 out. 2013.

. Disponível em: <www.tst.jus.br>. Acesso em: 15 ago. 2013; 19 ago. 2013; 23 ago. 2013; 06 set. 2013; 09 set. 2013; 20 set. 2013, 27 set. 2013; 11 out. 2013; 13 out. $2013 ; 15$ out. $2013 ; 10$ dez. 2013.

TRT DA 3 ${ }^{a}$ REGIÃO. Disponível em: <www.trt3.jus.br>. Acesso em: 15 set. 2013; 13 out. 2013.

US SUPREME COURT CENTER. Evans v. Abney - 396 U.S. 435 (1970). Justia.com. Disponível em: <http://supreme.justia.com/cases/federal/us/396/435/>. Acesso em: 30 set. 2013. 